\title{
Towards the techno-social Uncanny
}

\author{
ALEXANDER MATTHIAS GERNER*
}

\begin{abstract}
This paper explores a technical unfinished half-method [Halbzeug] of a metaphorology (Blumenberg) of the technological other in its variations and the philosophical mise-en-scène of the techno-social uncanny. The roboticist Mori had revived the concept of a technological uncanny in human machine interaction in the spatial metaphor derived from a diagram of an uncanny valley in the reaction of a human being shaking an artificial hand in order to show why we feel a certain eeriness in relation to technological artefacts, a topic that gains importance today to reflect human technological automata relations with robots/AI/Avatars that mimic and socially resonate with humans and may even drive further technological transhumanism. Although in an artefact design approach uncanniness is said to be avoided in the humanlike automaton-human encounter this paper dwells on the critic of techno-social otherness avoidance by technological overcoming of obstacles and thus argues for a cybernetic uncanny that can't be avoided. This paper introduces in a broader sense than Mori's a philosophical dramaturgy of Emmanuel Levinas' temporal notion of the relation to the other, including a preliminary metaphorological variation of the temporal techno-social uncanny.
\end{abstract}

Keywords: metaphorology, philosophy of technology, techno-social uncanny, technological transhumanism, temporality.

\section{Introduction}

$\mathrm{H}$

ow we think, present and represent time as its Logos has a long human history, and metaphors and mythological approaches to time are intrinsic to time itself. Whatever we do with our limited time independently of the mode we refer to time and of our experience of temporality, we never or almost never avoid to speak in a mythological, metaphorical non-direct language, in images or even visions and dramaturgies of mise-en-scènes about pragmatic horizons in which time acts. Even when supposedly uncanniness is measured in a technical human-artefact relation, we refer to a metaphor such as the uncanny valley to express our thoughts in a timeline in which our reaction changes from uncanniness to familiarity with the technical object. Therefore the "classical ordering of time" - as Bernhard Waldenfels ${ }^{1}$ puts it well - will develop a "particular

* $\quad$ Centro de Filosofia das Ciências, Departamento de História e Filosofia das Ciências Faculdade de Ciências, Universidade de Lisboa, Lisboa, Portugal.

$\bowtie$ amgerner@fc.ul.pt 
coping strategy that will work against time's power," and its metaphorological groundings in three fundamental aspects that this paper develops:

a) The strategy of the demythologization of time, in which time should not appear as an impersonated conceptual persona as a time sovereign for instance, in the Greek chronological tradition, Time's mythological father Chronos ${ }^{2}$ eats its children - or any other symbolic, metaphorical or anonymous power, so that one strategy of disempowering time sovereignty defines identity not in temporal terms, but in spatial terms as fundamentally timeless, or "out of time" that is reassessed by a metaphorology $y^{3}$ of the uncanny of social time of the other, a 'face-to-face' in the sense of Lévinas. But instead of Chronos we might be haunted by fears of missing out; or worse, we might not even notice what scares us, as in 'an enhancement society' today ${ }^{4}$.

b) submitting time to a binary order or schemata such as material and form or outer and inner time, psychological and physical time. These

1. Waldenfels, Bernhard, “Time-Lag”, In: Bernhard Waldenfels, The Question of the Other. The Tang Chun-I Lecture for 2004. Hong Kong, The Chinese University Press 2007, 53-66. Here: 54-55.

2. Thus in Nietzsche the monsteriosity is not attributed to a specific conceptual personae and a narrative of mythical time - Chronos - that eats its children, but to the process of time as the principle of impossible return and necessary passing and thus the impossibility of running backwards, producing always already a past - an "es war". Therefore the fight against decay and vanishing is useless in the sense of Nietzsche because it is a "prayer" of "Insanity" that the justice and law of time is, that time has to necessarily eat its own children-"Und dies ist selber Gerechtigkeit, jenes Gesetz der Zeit, dass sie ihre Kinder fressen muss" a necessary principle of life the consequence would be a nihilistic ethos of a spectator of decay, catastrophe or apocalypse: "Alles vergeht, darum ist Alles werth zu vergehen!" Nietzsche, Friedrich (1988). Also sprach Zarathustra II, 180/30, Kritische Studienausgabe, hg. V. Giorgio Colli und Mazzino Montanari (dtv/de Gryther) München.

3. Metaphorology is not a new metaphor theory but a pragmatic stance on how to work on metaphor use. This means a metaphorology is a non-metaphysical treatment of the pragmatic role that metaphysical structures, as for example "absolute" grounding metaphors play in our thought and for our hypothetical reasoning and even in our scientific language, that following Descartes tries to avoid preliminary forms of expression. According to Blumenberg (1960) we can distinguish: 1) Mere additional "preliminary" metaphors, easily to be substituted by clearer descriptive or technical language or other formalizations 2) Metaphors as a) an indicators of unclear concepts and b) - I would add - underdeveloped relations between concepts and their metaphors and c) metaphors as indicators of emerging knowledge fields, crossing, converging or diverging and shifting catalytic and take-over of knowledge "fields" (with all its positive heuristic aspects) and important for further research and development of (inter-)disciplinary knowlege and theory formation 3) Absolute founding metaphor of thought as a signal of in-conceptuality (Unbegrifflichkeit).

4. Armin Grunwald, “Are we heading towards an Enhancement Society?” In: Hildt, Elisabeth, Franke, Andreas G. (eds.). Cognitive Enhancement. An Interdisciplinary Perspective. Edited by Dordrecht: Springer Dordrecht, 2013: 201-216.

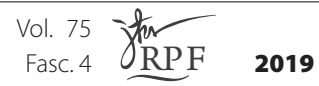


dichotomies of time in a radical phenomenological ${ }^{5}$ tradition such as in Lévinas could be repositioned as time in an aesthetic world intertwined with what it actually determines.

c) Time conceived as a member of oppositions, such as time and space, time and eternity, temporal flowing/flux vs. standing/static, following temporal instances in succession or standing out of each other in extension. 'Time flies:' we are almost always "running out of" time. Levinas' concept of social time distinguishes itself from classical Western concepts of time. As the philosopher himself underlines the importance of his own philosophical project as temporal in which the notion of a deformalization of time is proposed as a paradoxical immemorial past and a future that will never be my presence but is a condition of the other:

The essential theme of my research is the deformalization of the notion of time. Kant says it is the form of all experience. All human experience does in fact take on a temporal form. The transcendental philosophy descended from Kant filled that form with a sensible content coming from experience or, since Hegel, that form has led dialectically toward a content. These philosophers never required, for the constitution of that form of temporality itself, a condition in a certain conjuncture of "matter" or events, in a meaningful content somehow prior to form. (...) Perhaps what I have told you about the obligation toward the other prior to all contract (a reference to a past that was never present!) and about dying for the other (a reference to a future that will never be my present) will seem to you, (...), like a preface to possible research. ${ }^{6}$

To understand this deformalization of time let me put this in a personal mise-en-scène: When my father was in the hospital dying, with a heart valve disease, and it was too late for him to be medically treated, he was given a morphine derivate of palliative medicine. This was a way to partially relieve his symptomatic state of dyspnea, and to buy him some time to take him out of the agony of not catching enough air to breathe. Thus, being offered a pharmakon at times in commonly decided palliative medicine praxis to take away the feeling of drowning inside his lungs

5. Waldenfels speaks of Husserl's time having its own temportality as a "logos in an aesthetic world"(Hua XVII, 297 cit in Waldenfels 2007, 55, that in Merleau Ponty is put forward as a "vortex" of time Cf. Waldenfels, Bernhard, Giuliani, Regula, "Wirbel der Zeit", in: Waldenfels, Bernhard. Idiome Des Denkens: Deutsch-Französische Gedankengänge II. (Frankfurt am Main: Suhrkamp, 2005).

6. Emmanuel Lévinas, The Other, Utopia and Justice, in: Emmanuel Lévinas, Entre Nous. Thinking of the Other, Translated from the French by Michael B. Smith and Barbara Harshav, (Columbia University Press: New York, 2009), 223-234, here: 232-233.

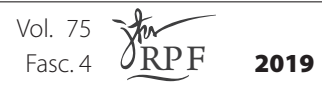


filling up permanently with liquid, was a form of being in a time that rested. This medically and technically offered time - at specific socially programmed times in which no communication with his family members was possible - although I might have been present at least once - I experienced him slip into 'another other' existential time-zone, which is absent in any temporal world map. A possibility of sleep and dream was the base for this time of his life? To take him out of an over-conscious programme of self-reflexive taking-notice-of-himself-dying as a hyper-anxious time of excessive solitude of existing merely towards his death. Then once, he confounded me and my face with the face of his grandfather. He mistook me and encountered by my proximate face someone he had deeply loved before, when being a child. What in the end was not crucial was the strangeness of misattributing my face to his grandfathers', as my face became an uncanny medium of diachronic ${ }^{7}$ time, a kind of generational "experience misunderstood". However, primarily, we were in our last alive encounters and in an impossible ability in the face of death, a birth of an a-synchronic time of a past that was never mine, and a future that would never be his, nor synchronically ours, or of my children that never met him: Not our death, but the death of a beloved other human being that we

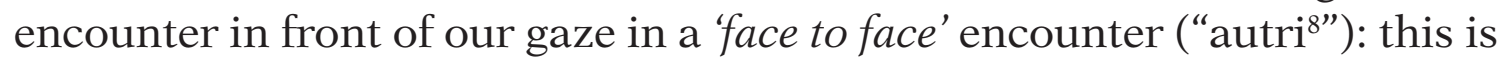
at the heart of the anxiety of losing love, and it most seriously lies before us as a radical ethical stance that asks the question posed by Derrida and Levinas: "Who is my neighbour?" And the question: What has the Other to do with what forces me to think?

In this social lag of time within the encounter of the Other we are always already too late to react to what affects us and always already too early for the future that turns into a non-lived past, and this is my point

7. "Diachrony, through the diastasis or dephasing of the instant and the recuperation of the divergency by retention, shows itself as a continuous and indefinite time in memory and in history, that is, a time that can be assembled in a present." Lévinas Emmanuel. Otherwise than Being or beyond Essence. Translated by Alphonso Lingis. Originally published as Autrement qu'etre ou au-deLa de l'essence, Phaenomenologica 54 (Boston: Martinus Nijhoff, 1991), 162.

8. Cf. Waldenfels, Bernhard. Sozialität Und Alterität: Modi Sozialer Erfahrung. (Berlin: Suhrkamp, 2015), 61. In the note 21 a distinction into a timeless eternal alterity, the Other as absolute and in capital letter, and a human-based social based alterity that goes through the medium of singlar human beings and concrete inbetween encounters is hinted at: „Zur singulären Form des autri, die bei Levinas den anderen Menschen meint in Unterschied zu l'Autre als dem absolut Anderen, vgl Delhom 2000, S.78-81, $103 \mathrm{f}$. Thomas Bedorf schlägt vor, zwischen primärer unendlicher und sekundärer sozialer Andersheit zu unterscheiden (2010, S.139, 141, 149). 
of view that the encounter with artefacts that resemble humans in their dynamics of uncanniness will foster this encounter of the other.

I will now explore a pragmatic tool and unfinished technical "Halbzeug"9 of a metaphorology ${ }^{10}$ (Blumenberg) within the conceptual distance of a techno-social inconceptuality of time of the Other in Levinas social alterity mise-en-scène of temporality in relation to uncanny technical artefacts.

\section{Towards a metaphorological variation of the techno-social Uncanny}

We model ${ }^{11}$ time with artefacts such as clocks - or calendars - in our

9. For Blumenberg the introduction of the technical term of an industrial production process "Halbzeug" is far from an idea of "half-knowledge" that could be interpreted as something not only substantially vague,but incorrect, faulty or defective, as the "Halbzeug" is a necessary step in the achievement of an enhanced outcome of a technical object, it is a still articulated to the semi-finished product mold and as such Halbzeug is used in Blumenberg as a meta-metaphor that lies at the pragmatic foundation of a principle unfinishable work on metaphors as a pragmatic model: "Was ich hier vorlege ist ja ohnehin nur Halbzeug, und die Perfektion und Lückenlosigkeit, mit der man über >das Sein< handeln kann, ist auf diesem Felde ganz unerrreichbar. "Hans Blumenberg, Paradigmen zu einer Metaphorologie. Kommentar von Anselm Haverkamp. (Suhrkamp: Frankfurt, 2013), 33. For Haverkamp the central idea of what a metaphorology is about, is exactly given in the industrial metaphor of Blumenberg`s use of "Halbzeug" as it shows a half-finished industrial technical mesh that is built of raw materiality and that is unfinished. While its utility has gaps, this imperfect tool can be used pragmatically and applied in the middle of the development process of (industrial) production: to access the modes of theoretical use, the standard of which can only be the truthful concept (Begriff), Halbzeuge are states of imperfect technisation and of inconceptuality. As Haverkamp explains well, the metaphor of Halbzeug shows how the standard between the raw material and the functional product, which has become a paradigm, the semi-finished industrial product makes the pragmatic epistemological essence of every metaphor tangible and raises it to the level Cassirer had in mind, in which an ambiguity prevails between functional optimization and mythical resubstantialization - an ambiguity that while longing for technical perfection, should tend to prevail as a metaphor. Cf. Anselm Haverkamp, "Kommentar". In: Hans Blumenberg, Paradigmen zu einer Metaphorologie. Kommentar von Anselm Haverkamp. (Suhrkamp: Frankfurt, 2013), 191-515, here: 230-321.

10. “(...) metaphorology seeks to burrow down to the substructure of thought, the underground, the nutrient solution of systematic crystallisations; but it also aims to show with what "courage" the mind preempts itself in its images, and how its history is projected in the courage of its conjectures." Hans Blumenberg, Paradigms for a Metaphorology. Translated by Robert Savage. (Ithaca, NY: Cornell University Press, 2016), 5.

11. Blumenberg denotes that metaphors are used as "implicative model.": "This means that metaphors, in the function discussed here, do not need to appear as such in the lexical sphere of expression; but a collection of statements suddenly coalesces into a meaningful unity if the leading metaphorical representation from which these statements were 'read

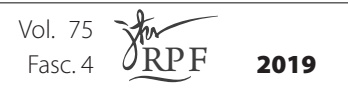

Provided for Personal License use. Not for reproduction, distribution, or commercial use.

(C) 2019 Revista Portuguesa de Filosofia. All Rights Reserved. 
metaphorical and metaphysical language that with Hans Blumenberg as a meta ${ }^{12}$-metaphorologist can give us a notion of how we pragmatically access the world with and working on temporal "founding" metaphors. Blumenberg claims that the world as a clock without indicators had been used as - I would add "uncanny" - a mechanical metaphysical explanation of the mechanical world view ${ }^{13}$, i.e., time as a mechanism. In what follows, I will attempt to demonstrate how time in the meta-metaphor of the Other as social encounter of a Face to Face is at Lévinas' base of his radical ethical philosophy that is different to a time of speech, a temporality of forgetting and remembering, or even a time of the senses of movements and rhythms ${ }^{14}$.

When we revisit the rich history of Western ideas of time and diverse thinking of a philosophy of time, we might find uncanny oppositions, time

off' can be hypothetically ascertained." Hans Blumenberg, Paradigms for a Metaphorology. Translated by Robert Savage. (Ithaca, NY: Cornell University Press, 2016), 21.

12. Cristian Strub collapses the distinction of "Letztmetaphern" and Metametaphern that are not metaphors of metaphors but that show how we access our world in totality. For Strub, this Meta-metaphorology is from its very beginning a discipline of a critic of Metaphysics, as it negates that there could be a conceptual, methodological language that would be non-metaphoric. In this sense, a Meta-metaphorology acts as the destruction of the legitimacy claim of a transcendental meta-language. Cf. Strub, Christian, "Wer hat Angst vor grünen Gläsern? Eine These zur Historizität und Normativität der Metametaphorologie, In Alexander Friedrich, Petra Gehring, and Andreas Kaminski, eds. "Metaphern Als Strenge Wissenschaft.", Journal Phänomenologie 41/2014 (2014): 57-62.

13. Hans Blumenberg, Paradigmen für eine Metaphorologie, (Suhrkamp: Frankfurt am Main, 2015), 101, in relation to the hypothetical access to phenomena of "organic" and "mechanical" background metaphorics states in relation to the world as machine and clockwork until the end of time: "Machines in the narrower sense (for transporting goods or laying siege) fall into this category by virtue of their ability to astonish the unknowing spectator; that is why the expression has accrued so much of its history in the theatre, where the effect on the spectator is no longer incidental. So far as I am aware, there is no precedent in Greek for the composite term Machina Mundi. (...) The nondescriptive and unspecific expression Machina Mundi is first endowed with a momentous specificity by the clockwork metaphor, suggesting the idea of a spring mechanism that, having once "been wound up, can be relied on to tick smoothly and continuously until the end of time. We get a sense of just how little our 'machine' has in common with the meaning of machina when we recall that the Middle Ages could isolate precisely these 'mechanical' components in Ingenium, the basis for the corresponding early forms in the Romance languages (Spanish: engenno; French: engin)". Hans Blumenberg, "Paradigms for a Metaphorology", 115-116.

14. "If all things were to remain the same to flow into one another, and if nothing stood out in contrast to something else, then there would be no rhythm. One would always be stepping into the same river, and even this sameness would have nothing from which it could stand out. In this sense, rhythm takes on an elementary function of supporting order" Waldenfels, Bernhard, "Time - Lag", In: Bernhard Waldenfels, The Question of the Other. The Tang

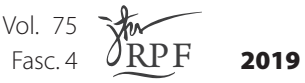


divided into twins, pairs, doubles or time and its ghosts or even phenomenological spectres ${ }^{15}$. These doubles of time are multiple, given in categories such as a) chronological time, determining an age of an (carbon-based ${ }^{16}$ ) object in a specified chronology vs. the order of a b) kairological time of an event to happen in an order of a right time to decide in a being that is conscious of its own economic time limits. Another example would be the distinction of "Lebenszeit", including Husserl's universal "flow" of immanent time-consciousness ${ }^{17}$ and Weltzeit ${ }^{18}$ (Blumenberg ${ }^{19}$ ), an resil-

Chun-I Lecture for 2004. Hong Kong, The Chinese University Press 2007: 61.

15. "A specter of solipsism haunts transcendental phenomenology" Nicolas de Warren, Husserl and the Promise of Time: Subjectivity in Transcendental Phenomenology. (Cambridge: Cambridge University Press, 2009), 209; Cf. Laclau's annotation that Derrida's idea of production of techné is intrinsically linked to spectral spiritualization of trauma related to the sense of Freudian traumatic decentering of mankind after Marxism and after the instances responsible for time out - of-joint alias traumata in human self-conservation strategies a) the Copernican decentering of Earth as out of the world's centre b) the decentering as mankind's biological descent (Darwin's Evolution and human-ape descent as out of the evolutions center) the decentering of consciousness (the Power of the unconsciousness; Freud). Cf. Ernesto Laclau, "The Time Is out of Joint.' " Diacritics 25, no. 2 (1995): 85-96. https://doi.org/10.2307/465146. Cf. Jacques Derrida, Spectres of Marx: the State of the Debt, the Work of Mourning, and the New International. (New York: Routledge, 2011), specially 96-117.

16. Such a chronological method is the radiocarbon method, also known as radiocarbon dating, 14C; C14 dating or radiocarbon dating, or radiocarbon dating is a method for radiometric dating of carbon-containing materials, especially organic materials. The temporal application range is between 300 and about 60,000 years. Cf., Willard Libby, Radiocarbon Dating. (Chicago: The University of Chicago Press, 1955).

17. Edmund Husserl, Zur Phänomenologie des inneren Zeitbewusstesens (1893-1917). Ed. R. Boehm. (= Husserliana X). (The Hague: Martinus Nijhoff, 1969).

18. The idea that we live in a world time an epochal "age of machine intelligence" comes with an old metaphor of taking care in advance before a catastrophic "flood" - related to our time of climate change - of AI and that is adopted in the field of human-machine relations and hinges on Blumenberg's existential metaphor of "Shipwreck with spectator": "Computers are universal machines, their potential extends uniformly over a boundless expanse of tasks. Human potentials, on the other hand, are strong in areas long important for survival, but weak in things far removed. Imagine a "landscape of human competence," having lowlands with labels like "arithmetic" and "rote memorization," foothills like "theorem proving" and "chess playing," and high mountain peaks labeled "locomotion," "hand-eye coordination" and "social interaction." (...) I propose that we build Arks as that day nears,and adopt a seafaring life!" a metaphor of Hans Moravec cited an illustrated in: Max Tegmark on general Human-Level AI: in Life 3.0: Tegmark, Max. Life 3.0.: Being Human in the Age of Artificial Intelligence. New York (New York): Alfred A. Knopf, 2017, 74-75.

19. Hans Blumenberg, Lebenszeit und Weltzeit (Frankfurt am Main: Suhrkamp, 1986). The problematic of Blumenberg's impossibility of living our lives in harmony with the world (and its respective loss) is the problematic of historicity, finitude and contingence that we all die too soon. Cf: César González Cantón “Absolutism: Blumenberg's Rhetoric as

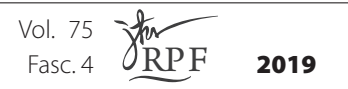

Provided for Personal License use. Not for reproduction, distribution, or commercial use.

(C) 2019 Revista Portuguesa de Filosofia. All Rights Reserved. 
ience of human self-conservation given as a necessary gaining of distance or gap or deviation of our sense-funding human lived lifetime from an all-consuming absolutism of reality ${ }^{20}$, given in measurable or countable world-time.

Another example would be the dichotomy of cosmological and scientific time of clocks and physical chronometric dating techniques vs. phenomenological and subjective time of duration, or existential experience of temporality in retention, presence/ presentification and protention, while others think time as a negative experience or even a negative ${ }^{21}$ theology of time, opposed to positive measurement and vice versa, a loss or a lack or even a time out of joint.

Can we actually access the otherness of time by ourselves in solitude? However, only by the encounter with the other, we cannot enter the river of time twice at the same time, if not we have even to see that time as other might be the existential threat of a "river without shore" (Fluss ohne Ufer ${ }^{22}$ ), without a clarifying "arrow" of time and its directionality or orientation, but as complex system of an ocean ${ }^{23}$ and with multiple and parallel currents of recurring, but never repeating times dependent on the currents of others. We have (too) little time together, let us use it carefully to maintain not purely memory in itself but as a rebellion against the indifference of time, in which not forgetting might be a rebellion against humanity (Blumenberg ${ }^{24}$ ), but instead: let us think and maintain the experience of the other in the sense of Lévinas.

As metaphorology becomes a crisis phenomenon of the ideal of logocentrism, Blumenberg has pointed out that metaphors and rhetoric are no less important for human thought, including philosophy ${ }^{25}$ as paradigms

Ontological Concept" (103-142). In: Hans Blumenberg, Nuovi paradigmi d'analisi a cura di Alberto Fragio e Diego Giordano. (Roma: Aracne, 2011), 106.

20. For Blumenberg the human relation towards reality is metaphoric: "Der menschliche Wirklichkeitsbezug ist indirect, umständlich, verzögert, selektiv und vor allem 'metaphorisch"'. Hans Blumenberg, Wirklichkeiten in denen wir leben. Reclam: Stuttgart, 115.

21. Michael Theunissen, Negative Theologie Der Zeit. (Frankfurt am Main: Suhrkamp, 1991).

22. Cf. Hans Henny Jahnn, Fluss Ohne Ufer: Roman in Drei Teilen. Edited by Ulrich Blitz. (Hamburg: Hoffmann und Campe, 2014).

23. „Sie \{die Zeit\}ist kein Strom. Sie ist ein Meer.“ Hans Jahnn, Henny. Fluss Ohne Ufer: Roman in Drei Teilen. Teil II, Edited by Ulrich Blitz. Hamburg: Hoffmann und Campe, 2014, S. 289.

24. Hans Blumenberg, Außenansicht, in: Hans Blumenberg, Die Vollzähligkeit der Sterne. Frankfurt: Suhrkamp, 371-373 here: 373.

25. Cf. e.g. Cristian Strub, "Gebäude, organisch verkettet. Zur Tropologie des Systems" (108-135), in: Anselm Haverkamp,. Metaphorologie: Zur Praxis Von Theorie. (Frankfurt

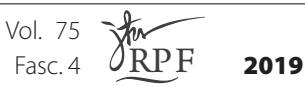


creating entities, and behavior than clear, logical definitions to clarify the tensions in phenomenology in between a) metaphor and concept b) or between conceptuality and inconceptuality (Unbegrifflichkeit ${ }^{26}$ ).

This goes beyond the primordial scene in the Aristotelian relation of cosmos and logos in book Gamma of his Meta-physics ${ }^{27}$. Thus, Blumenberg - beyond Heidegger's diagnosis ${ }^{28}$ - in his half-method can categorically put forward a "meta-kinetics"29, a meta - movement in which the history of philosophical concepts does not add a new theory or model of metaphor, but shows how the pragmatic work on metaphors as a pragmatics of metaphysics are made fruitful, as in the endless human processual endeavor to understand not only what is possible to be put into a scientific explanation, but more so in which way our mind preempts itself in the images we think with, and how these contribute to the conjectures we make and the time we are with the other.

Blumenberg' s metaphorology (1960) is based on the thematization and clarification of natural philosophical phenomena. Metaphorology, therefore, is a non-metaphysical treatment of the pragmatic role that metaphysical structures, for example, "absolute" metaphors play in our thought and for our hypothetical reasoning that enters very well-defined functions.

For Blumenberg concepts as well as metaphors act at a distance in inconceptuality ${ }^{30}$, mostly in the absence of their objects and far from a

am Main: Suhrkamp, 2009).

26. Hans Blumenberg, Theorie Der Unbegrifflichkeit. Hrg aus dem Nachlaß von Anselm Haverkamp. (Frankfurt am Main: Suhrkamp, 2010).

27. Cf., Cassin Barbara \& Michel Narcy, La decision du sens: Le Livre Gamma de la Metaphysique d'Aristote, (Paris: Vrin 1989), 10, cited in: Anselm Haverkamp, Hans Blumenberg, Paradigmen $\mathrm{Zu}$ Einer Metaphorologie Kommentar. (Frankfurt, M.: Suhrkamp, 2013), 232.

28. Cf. Heidegger, Martin. Der Satz Vom Grund. Gesamtausgabe. 1. Abteilung: veröffentlichte Schriften 1914-1970. Vol. 10. (Frankfurt am Main: Klostermann, 1997): 135.

29. "Auch absolute Metaphern haben daher Geschichte. Sie haben Geschichte in einem radikaleren Sinn als Begriffe, denn der historische Wandel einer Metapher bringt die Metakinetik geschichtlicher Sinnhorizonte und Sichtweisen selbst zum Vorschein, innerhalb deren Begriffe ihre Modifikationen erfahren. "Hans Blumenberg, Paradigmen für eine Metaphorologie. Kommentar: Haverkamp. (Suhrkamp: Frankfurt), 16.

30. "Der Begriff ist aus der actio per distans, aus dem Handeln auf räumliche und zeitliche Entfernung entstanden. "Hans Blumenberg, Theorie Der Unbegrifflichkeit. Hrg aus dem Nachlaß von Anselm Haverkamp. (Frankfurt am Main: Suhrkamp, 2010), 8-11; for the topos of inconceptuality see: Oliver Müller (2011)»Von der Theorie zur Praxis der Unbegrifflichkeit. Hans Blumenbergs Paraethik«, in: Anselm Haverkamp; Dirk Mende (Hg.): Metaphorologie. Zur Praxis von Theorie. (Frankfurt: Suhrkamp, 2009), S. 256-282.

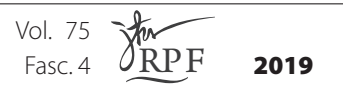


theoretical observational stance of solid ground or neutral fence sitter starting with a clear horizon ${ }^{31}$. Metaphors are called into their pragmatic function even in the incompleteness of the underlying imagination or thinking of beings limited in time and thus submitted to pragmatic-economic restrictions of instrumental reason. In reason, such a pragmatic performance from a distance includes kinds of objects such as ideas or rules, as-if (being) - objects that never can be made present: the world, the I, space and as well the topic: Time as Other.

It is worthwhile noting that Blumenberg in his thoughts on inconceptuality states that time cannot be treated as a finite or well-circumscribed object. This non-object does not make a stand against $\mathrm{x}$ (Gegenstand). The inconceptual, thus, in its very imaginations and representations is always already a lack of completeness. Nonetheless, rationality approximates us with such a competence besides our distance towards the phenomena of time, space or world. The distance towards the reality of the "Gegenstand," however - makes another way of approaching time necessary: a metaphorology of the absolute ${ }^{32}$ metaphors of temporality such as a clock

31. Blumenberg in his posthumous studies on the metaphorology of springs, streams and icebergs - Hans Blumenberg, Quellen, Ströme, Eisberge. Ed. aus dem Nachlass by Bülow Ulrich von and Dorit Krusche. (Berlin: Suhrkamp, 2012). Referes to the paradoxes and conceptual difficulties that the last Husserl gets when trying to combine his concept of the phenomena in the "horizon" metaphoric of a dawning clearity and the Heraclitan "stream" metaphorics into harmony. As Heraclitus said that no one could climb into the same river twice, Blumenberg insists that this is an absolute metaphor, and one of the earliest achievements of philosophy, that reality cannot be held fast because it is not what it seems to us. Thus, Blumenberg shows Husserls first traces of difficulties of the philosophical aim to go towards the things themselves. Metaphorological contradictions of the "Schwierigkeiten an der Sachen selbst" hint to the fact that a reflective self is unable to stay on a solid grounds of a single point of view. Therefore, we cannot speak from a clarified temporal position in which a clear separation of retention or protention would be valid, but actually we are pulled together with the waters of the temporal subjective stream in which the researcher has even to swim with the stream, in order to describe phenomena of the flux of the world. Cf. Friedrich, Alexander, Philosophisches Heimweh. Eine metaphorologische Studie zur Phänomenologie Edmund Husserls. In: Alexander Friedrich, Petra Gehring, and Andreas Kaminski, eds. "Metaphern Als Strenge Wissenschaft." (7-41), Journal Phänomenologie 41/2014 (2014): 38.

32. Blumenberg notes that ideality of concepts of reason necessarily imply a weakness in contextual determination and thus lead to the pragmatic functional use and performance of absolute metaphors that in their resistance towards context are called absolute (Cf. Hans Blumenberg, Theorie der Unbegrifflichkeit, 65); Kaminski notes that in Blumenbergs Paradigmata especially metaphors of truth have been treated as absoluteness of absolute metaphors in four characteristics. 1) Concepts cannot equivalently substitute absolute metaphorical expression. 2) In the sense of Blumenberg absolute metaphors such as Power or powerlessness of truth, the world or universe as machine, the book of nature in which

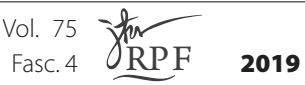


without indicators of hour, minutes or seconds or any other abstract entity of measurement, the "river of time" in which one as an embodied and limited being never enters twice the same, or the uncanny encounter of the Other in which time is given as a "face-to-face" (Levinas) beyond mere phenomenology of the social encounter. Thus, the alterity that we experience within these technical "Halbzeuge ${ }^{33 "}$ in the metaphors we apply to experience and understand time. Time in Lévinas is merely approachable as a paradoxical metaphorical mise-en-scene of distance that is proximate or proximate distance:

All description of this "distance-proximity" could not be elsewise than approximate or metaphorical, since dia-chrony of time in them is the non-figural meaning, the literal meaning, the model. ${ }^{34}$

Do we always live in the same time? How could an economically ${ }^{35}$ synchronized totality notion of time in measuring timelines, deadlines

one can read are non-verifiable or theoretically decidable. 3) Absolute Metaphors provide for a pragmatic orientation, they give a structure to a world, representing the never fully experienced totality of reality. 4) Absolute Metaphors are models and "settings" (Blumenberg) between I and the world about totality horizons that are read off and "push through to the expressive sphere in form of metaphors" (Blumenberg, Paradigms, 7.). Kaminski, Andreas, "Was heißt es, daß eine Metapher absolut ist? ", Journal Phänomenologie, In: Alexander Friedrich, Petra Gehring, and Andreas Kaminski, eds. Metaphern Als Strenge Wissenschaft. Journal Phänomenologie 41/2014 (2014), 47-62.

33. In the Brother Grimm's lexicon of the German Language Halbzeug gets the following-shortentry referring to the example of use in an unfinished papermaking process in teh Romantic Time. This is exemplified by the paper that is still in the making or a "lumpen" or "mesh", that is a gross structure that has not passed the paper press and cut in exact measured pieces and as such is not a finely workout out piece of paper: "halbzeug, m.in der papiermühle noch nicht völlig zerstoszene lumpen: die gröblich zerstampften lumpen oder der halbzeug. Beckmann technologie (1777)s. 71. davon halbzeugkasten, trog zur aufnahme des halbzeuges. Jacobsson2, 195a "Deutsches Wörterbuch von Jacob und Wilhelm Grimm. 16 Bde. in 32 Teilbänden. Leipzig 1854-1961. Quellenverzeichnis Leipzig 1971. halbzeug bis haldung (Bd. 10, Sp. 221 bis 223). Online-Version Wörterbuchnetz - Deutsches Wörterbuch von Jacob Grimm und Wilhelm Grimm. Accessed October 30, 2019. http://woerterbuchnetz.de/ cgi-bin/WBNetz/wbgui_py?sigle=DWB\&mode=Vernetzung\&lemid=GH01348\#XGH01348.

34. Emmanuel Lévinas, Time and the Other: and Other Essays. Introduction. Translated by Richard A. Cohen. (Pittsburgh, PA: Duquesne University Press, 1987).

35. Christina Beckert as well speaks of an economic life and the invention of a totalitarian economic society in which the relation of the I with totality is essentially economic and opposed to an absolute future never mine or canny in the sense of feeling mine or at home, that I would formulate as the base of the absolute uncanny and its metaphorology in Levinas, not related to a home to come back to or a Dasein in this world, Beckert, Cristina. Subjectividade e Diacronia No Pensamento De E. Levinas. 2nd ed. (Centro de Filosofia da Universidade de Lisboa, 2010), 91-92.

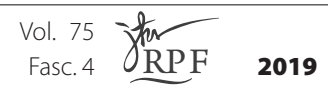


and spatial diagrams have ever been my or our time in the encounter of the other? Time as diachronic and deferred to a future that I can't possess in the human encounter of the face to face of the other becomes social for Levinas and is in itself diachronic. Temporality is not seen here as a classical phenomenological egologic - nor as a minor physical problem of measuring time as shown by artefacts of mechanical clocks or seasonal calendars of natural time and its forecast. Instead of a meteorological, we follow what can be called a metaphorologic account of uncanny time.

In uncanny time we seem not to be home at such an economically invested synchronized time: in a there is of time as such, and such a time, we stay out-of-time: in full solitude. As a result of a "horror" the plenty solitude, which is the opposite of nothingness, I treat techno-social uncanniness of time. We go wrong in thinking that by synchronizing to an economic-technological model of time that is never ours, we would be in time. However, we seem to recover time on weekends, to recover sleep time that we lost in insomnia, or to spare some erotic time and even family time beyond the counting clocks and bells of artefacts and automata of time, repaying ourselves for our permanent payments of being out of time. The "Men in Grey", the time-thieves of Michael Ende's much more than a children's novel "Momo" come to mind, that rule our commodified temporal world or the surreal, playful automaton that we have to animate with our muscle power and work-contracts of " $\mathrm{X}$ " horas and " 0 " payment of the surreal "Fulfillment Center Machine" of Tim Hutchin" ${ }^{36}$ : the time of the world - "Weltzeit" - implies for Heidegger something uncanny, an Unheimliches.

Fleeing from a "Unzuhause" 37 , a nonhome in itself already is present in Freud's Text from 1919 on the Uncanny treating the paradoxical a-synchronic primary attraction and secondary repulsion and recall of a

36. Tim Hunkin, "Fulfillment Centre In Use Youtube", February 12, 2019. https://www. youtube.com/watch?time_continue $=1 \& v=N r 4 f d X t R J X Q \&$ feature $=e m b \_t i t l e$.

Cf. http://www.timhunkin.com/a225_fulfilment-center.htm

37. Mark Fisher in his book "The Weired and the Eerie" criticizes Freud's equaling the term "uncanny" with both the "eeri", ghostly and the "weired", strange: "Perhaps my delay in coming round to the weird and the eerie had to do with the spell cast by Freuds concept of the unheimlich. As is well known, the unheimlich has been inadequately translated into English as uncanny; the word which better captures Freud's sense of the term is the "unhomely". The unheimlich is often equated with the weird and the eerie - Freuds own essay treats the terms as interchangeable. But the influence of Freuds great essay has meant that the unheimlich has crowded out the other two modes." Fisher, Mark. The Weird and the Eerie. (London: Repeater Books, 2016), 9.

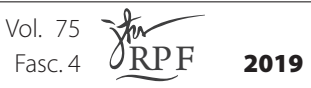


non-treated trauma in the past childhood ${ }^{38}$. As a result of this Freud criticizes Jentsch's concept of the uncanny. He opposes Jentsch's view that the uncanny is a result of cognitive dissonance or intellectual uncertainty of something unfamiliar of not knowing where one was or unfamiliar with something, beyond the equation of the unfamiliar=unheimlich. Thus, Freud's Jentsch critic is directed against the situational account of novelty in the metaphor of the unhomely.

\subsection{The Unhomely in human-technology relations: metaphorological variations of the uncanny valley}

Roboticist such as Mori, see the Uncanny as a construction problem of similitude and mimicry or verisimilitude with human morphology. In Mori's view the question is posed how to overcome the feeling of uncanny in relation to machines which he describes with the metaphor of the uncanny valley (Mori), uncanny cliffs (Bartneck, Kanda Ishiguro, Hagita $\left.2007^{39} ; 2009^{40}\right)$, uncanny walls ${ }^{41}$, an uncanny mountain ${ }^{42}$ (Newman, 2015).

38. In Freud's view of a return of a repressive past, the story of E.T.A. Hoffmann's “The Sandman" is staged in a mise en scene of horror as the tearing out of the eyes as repressed castration anxiety that then is interpreted in the Sandman character as a demonized father. The story thus evokes for the father of psychoanalysis the horrors of childhood, which - deviated and repressed into the unconscious - would be still eerie in us and would then be recalled while reading.

39. Christoph Bartneck, Takayuki Kanda, Hiroshi Ishiguro, and Norihiro Hagita. "Is The Uncanny Valley An Uncanny Cliff?” RO-MAN 2007 - The 16th IEEE International Symposium on Robot and Human Interactive Communication, 2007. https://doi. org/10.1109/roman.2007.4415111.

40. Christoph Bartneck, Takayuki Kanda, Hiroshi Ishiguro, and Norihiro Hagita. "My Robotic Doppelgänger - a Critical Look at the Uncanny Valley.” RO-MAN 2009 - The $18^{\text {th }}$ IEEE International Symposium on Robot and Human Interactive Communication, 2009. https://doi.org/10.1109/roman.2009.5326351.

41. Angela Tinwell, Mark Grimshaw, and Andrew Williams. “The Uncanny Wall.” International Journal of Arts and Technology 4, no. 3 (2011): 326. https://doi.org/10.1504/ijart.2011.041485.

42. "This can be seen most clearly in the central section of The Universe of Things: a series of experiments in inverting the "uncanny valley." Shaviro doesn't coin a phrase, but we could call the phenomenon that interests him "the uncanny mountain," meaning something like: "a human agent's rise in vitality as it becomes increasingly object-like." Whitehead serves as Shaviro's guide in navigating this "uncanny mountain." In The Universe of Things Shaviro looks in particular at Whitehead's close reading of Percy Bysshe Shelley's 1817 poem Mont Blanc. By way of Whitehead, Shelley also provides Shaviro with The Universe of Things' title. ("My own, my human mind, which passively/ Now renders and receives fast influencings,/ Holding an unremitting interchange/ With the clear universe of things around")". It is not too far of a stretch, then, to think of Mont Blanc as the original "uncanny mountain.” Kurt Newman, “Panpsychism’s Labyrinth. Steven Shaviro's New Book Teaches

$$
\begin{aligned}
\text { Vol. } 75 \\
\text { Fasc. } 4
\end{aligned} \underset{\mathrm{RPF}}{2019}
$$


All these metaphors of eeriness and disorientation or undecidability in double perception should be confronted with an "uncanny canniness"43 in which machines have absorbed our homeliness, but still stay strange artificial players while we play with them. Recently the creation of AI Avatars and AI faces have at their foundation an eeriness of wishing to meet with someone, even if actually a something that is dead or inanimate and sooner or later crashes over our expectation of encountering a living face and vice versa.

With Levinas solitude could be at the core of the uncanny, as the moment and duration when we fall out of time, when the encounter with the socio-technical other gives way to finding in-animated objects that we endowed only with our life in the sense of Norbert Wiener. We only hear a disturbing horrible silence in sleeplessness without exit of an disturbing "there is" 44 in which uncanny sounds are described as "incessant buzzing that fills each silence" in the "there is" il y $a$, in which we do not encounter a living face, but we are again and again a subject separated from the given. Because time in Levinas is given as a social and ethical encounter. Let us thus introduce a preliminary metaphorology of the uncanny in human-techno encounters such as Uncanny valleys, asking if the design idea of overcoming ${ }^{45}$ the technological uncanny valley in human automata relation is actually feasible.

Us How to Navigate in a World Where Objects Are Peers." The New Inquiry, April 18, 2015. https://thenewinquiry.com/panpsychisms-labyrinth/.

43. "In playing against such a machine, which absorbs part of its playing personality from its opponent, this playing personality will not be absolutely rigid. The opponent may find that strategems which have worked in the past, will fail to work in the future. The machine may develop an uncanny canniness. It may be said that all this unexpected intelligence of the machine has been built into it by its designer and programmer. This is true in one sense, but it need not be true that all of the new habits of the machine have been explicitly foreseen by him." Norbert Wiener, God and Golem, Inc. A comment on certain points where cybernetics impinges on religion. (Cambridge. Mass. MIT Press 1964), 21-22.

44. "Essence stretching on indefinitely, without any possible halt or interruption, the equality of essence not justifying, in all equity, any instant's halt, without respite, without any possible suspension, is the horrifying there is behind all finality proper to the thematizing ego, which cannot sink into the essence it thematizes. (...) It is the incessant buzzing that fills each silence, where the subject detaches itself from essence and posits itself as a subject in face of its objectivity. A rumbling intolerable to a subject that faces itself as a subject and assembles essence before itself as an object. But its own subtraction is unjustifiable in an equal woven fabric, of absolute equity. The rumbling of the there is is the non - sense in which essence turns, and in which thus turns the justice issued out of signification." Otherwise than Being 163, my emphasis

45. Tom Geller, "Overcoming the Uncanny Valley." IEEE Computer Graphics and Applications 28, no. 4 (2008): 11-17. https://doi.org/10.1109/mcg.2008.79.

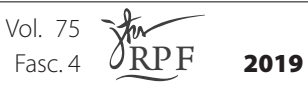


The unhomely bustling of essence - there is:

The other term of the alternative would likewise lie within this closure and these walls, but it would consist in letting itself be tempted by the labyrinths that open in the instant extracted from its retentions and its protentions - in the pleasure which is still not enough of a "cross section of time" in an instant, is still a dream running along the edge of nightmares and symbolisms, and seeks another time and a "second state" in intoxication and drugs, which are the far off outcomes or prolongations of the Epicurean innocence and purity. In it nonetheless pleasure was separated from the responsibility for another, and already love separated from law, and eroticism seeped in. An illusory solution, it is also inside essence and its play, without finding in essence itself a sense in a new or older signification. The dilemma is without a resolution; essence has no exits: to the death anxiety is added horror of fatality, of the incessant bustling of the there is, the horrible eternity at the bottom of essence. ${ }^{46}$

The technological uncanny has been called a characteristic of modernity ${ }^{47}$ and might be joint with the upcoming of mechanistic world views and philosophies and their artefacts such as clocks and automata that seem autonomous and even human-like. In this line of thought we should actually invert the perspective of an uncanny valley, to be overcome in Human-machine interface design as proposed by Mori - who rather follows Jentsch than Freud's fear, dread and horror related to the uncanny. Against Mori, I would argue less for building an uncanny valley roadmap to overcome it in human-robot relations design in which human face-interfaces can make such encounters "more human". Neither would I argue for a better hermeneutic understanding through robotics research what makes robots become similar to humans, finding out about the ideal dosage of human-likeness, and less even I would argue for design rules for creating devices "comfortable" for humans to accept. Norbert Wiener, on the other hand, proposed an interesting twist in his "uncanny canniness"

46. Emmanuel Lévinas, Otherwise than Being. Or beyond essence. Translated by Alphonso Lingis (Pittsburgh, PA: Duquesne University Press, 1998), 176.

47. Cf. "We ask - where does the uncanny come from? Why does it keep returning? Could it be that the uncanny is a distinctively modern experience? /While the uncanny has of course been significant as a theme in literature since at least the high Gothic, it is Freud's paper of 1919 that has become the key cultural resource. (...) Given a further fillip by the publication of Derrida's Specters of Marx in 1994, the influence of the uncanny throughout the academy was such that by 1998 Martin Jay could refer to it as the 'master trope' of the decade." Collins, Jo, and John Jervis. Uncanny Modernity: Cultural Theories, Modern Anxieties. (Basingstoke, Hampshire: Palgrave Macmillan, 2008).

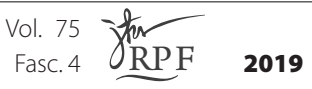


when referring to us humans playing a game with machines and that on a later stage these machines besides being created by us even alter themselves adopting habits in an uncanny canniness, that we might not distinguish anymore.

In Jentsch's 1906 account "Zur Psychologie des Unheimlichen" of the uncanny the psychological unsure feeling and doubt and a cognitive dissonance or intellectual uncertainty between aliveness and non-animate-ness ${ }^{48}$ is put at the core of the Heimlich/unheimlich dynamics that has temporal breakup points. Hereby, Jentsch brings the hyperreality of a wax figure ${ }^{49}$ and human-like live-size automata into play.

These automata perform complex tasks - playing musical instruments or dancing - and their seemingly or scarily autonomous activities such as playing a trumpet or showing movement convulsions as primary reasons for uncanniness in human reactions surprise us and lead according to Jentsch to intellectual dissonance in perception when the anticipated attribution of aliveness linked to the artistic design of artificial humans, fails to achieve its purpose and the simulation of special effects that the mechanic constructions and simulations of such technical mechanical objects as androids, sex-robots and human-like technical artefacts and their computer simulations including Avatars or computer-generated images (CGI's) and characters show leave us with an feeling of strangeness.

This overwhelming surprise effect can as well be described in one of the double notions of technology as Aristotle proposed - beside techné - in mechane: an overpowering effect in technology is put forward in which the fine mechanics of such artificial objects become verisimilar to human alive movement and thus create special effects of appearing as-if being a human, including the simulation of directional eye-gaze, artificial "consciousness" or affective response. In terms of imitation and substitution of a perceptual object that is animated but still is a non-alive thing Jentsch reminds us on a situation when a supposedly non-moving tree

48. Ernst Jentsch,. "On the Psychology of the Uncanny (1906)." Angelaki 2, no. 1 (1997): 7-16. https://doi.org/10.1080/09697259708571910. Here p. 11 Freud as well mentioned the aesthetic instantiation of the uncanny and examines the ETA Hofmann fiction story as well the Sandman (1817). While in Jentsch the female robot automaton Olympia lies at the core of the Uncanny for Freud it is located in the character of the Sandman himself, as an uncanny figure who tears out children's eyes.

49. Jentsch, 12.

$$
\begin{aligned}
& \begin{array}{l}
\text { Vol. } 75 \\
\text { Fasc. } 4 \text { RPF }
\end{array} \\
& 2019
\end{aligned}
$$


trunk is substituted in our illusionary perception by a giant snake ${ }^{50}$. This temporally de-phased perception of a fixed object that becomes alive in an instant, but in the moment of the factual refutation of the illusionary perception is located at the core of the techno-social uncanny.

\section{Mori's Diagram as Metaphor}

The roboticist Mori had revived the concept of the uncanny in the spatial metaphor derived from a diagram of an uncanny valley in order to understand why we feel a certain eeriness in relation to technological artefacts specifically robots/AI/Avatars that mimic humans. Mori's uncanny valley diagram is a metaphor. If we amplify the notion of metaphorology of philosophical and scientific concepts to images used in scientific research, that have as a foundation imagery a geometric symbolism ${ }^{51}$ (Blumenberg 2010) in general and a metaphorization of geocentrism, inscribed in a scientific research field such as in the human factors research on humanrobot interaction, then we can state that the symbolic line diagram representation, that forms a valley-like graphic structure introduced in $1970^{52}$ has been a very fruitful scientific-technological metaphor: the "Uncanny Valley", exploring implications for human - robot interaction and computer-graphics animation, or proposing models of biological ${ }^{53}$ and social

50. "someone sat down in an ancient forest on a tree trunk (...) to the horror of the traveler, this trunk suddenly began to move and showed itself to be a giant snake." Jentsch, 11

51. Cf. Hans Blumenberg, Paradigms for Metaphorology [Paradigmen zu einer Metaphorologie], (Frankfurt: Suhrkamp Verlag). Translated from the German and with an afterword of Robert Savage. (Ithaka New York, Cornell University Press, 2010), chapter X “Geometric Symbolim and Metaphorics", 115-132: Cf. Mori 1970: "An example of a function that does not increase continuously is climbing a mountain - the relation between the distance $(x)$ a hiker has traveled toward the summit and the hiker's altitude $(y)$ - owing to the intervening hills and valleys. I have noticed that, in climbing toward the goal of making robots appear human, our affinity for them increases until we come to a valley (Figure 1), which I call the uncanny valley."

52. Masahiro Mori, "The Uncanny Valley [From the Field]." Translated by Karl Macdorman and Norri Kageki. IEEE Robotics \& Automation Magazine 19, no. 2 (June 6, 2012): 98100. https://doi.org/10.1109/mra.2012.2192811. Reprint from: M. Mori, "The uncanny valley," Energy, vol. 7, no. 4, 1970 (in Japanese), here, 99.

53. In the realm of Social Neuroscience a double notion of temporal dimension is underlined in the sense of a prediction of an expected event that does not turned out as expected. The Technological uncanny is thus related to technology as prediction (Kaminski) or expectation, that in the situation of the technological uncanny is proven wrong. Cf. Saygin, Ayse Pinar, Thierry Chaminade, Hiroshi Ishiguro, Jon Driver, and Chris Frith. "The Thing That Should Not Be: Predictive Coding and the Uncanny Valley in Perceiving Human and Humanoid Robot Actions." Social Cognitive and Affective Neuroscience 7, no.

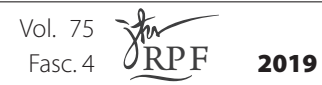


causes. Interestingly, as counterexample to an uncanny handshake Mori introduces a theater metaphor of the uncanny, in the human encounter with a traditional Japanese Bunraku puppet, that in its cultural acceptance of play is endowed with higher homeliness values.

\section{Uncanny Cliff}

The uncanny valley appears to be more of a cliff than a valley since even pictures of humans do not reach the level of pictures of toy robots. It has to be acknowledged that there is a small upward trend again towards highly human-like entities, which results in a small valley. ${ }^{54}$

In the variation of the metaphoric geologic morphology, the uncanny cliff, this geographic metaphor has as well been transformed into an uncanny slope, with only a weak uncanny effect ${ }^{55}$. Tinwell and colleagues, however, oppose the idea that the uncanny valley can actually be overcome and thus introduce a permanence and durational account of uncanniness in the relation of technical artefacts and human-like automata and human beings and the permanent reintegration of the weird. They propose a broader than mere lookalike appearance - mimetic approach to the technological uncanny, going into the realm of behaviour and introduce the habituation effect of seeing something as an artefactual reproduction and not as a real, alive human being:

(...) Our results imply that: (1) perceived familiarity is dependent upon

4 (2011): 413-22. https://doi.org/10.1093/scan/nsr025. See as well: "As numerous studies have succeeded in exposing such visual imperfections and connected them to negative evaluations, the phenomenon has been framed by theories such as pathogen avoidance (Ho, MacDorman, \& Pramono, 2008), mortality salience (MacDorman \& Ishiguro, 2006) or the fear of psychopathic individuals (Tinwell, Abdel Nabi, \& Charlton, 2013). Pursuant to these evolutionary psychological approaches, the aversion against human-like entities with slight defects might serve as part of a behavioral immune system (Schaller \& Park, 2011), shielding individuals against potential dangers to themselves or their progeny." Stein, JanPhilipp, and Peter Ohler. "Venturing into the Uncanny Valley of Mind - The Influence of Mind Attribution on the Acceptance of Human-like Characters in a Virtual Reality Setting." Cognition 160 (2017): 43-50. https://doi.org/10.1016/j.cognition.2016.12.010.

54. Christoph Bartneck, Takayuki Kanda, Hiroshi Ishiguro, and Norihiro Hagita. "Is the Uncanny Valley An Uncanny Cliff?” RO-MAN 2007 - The 16th IEEE International Symposium on Robot and Human Interactive Communication, August 26, 2007, 36873. https://doi.org/10.1109/roman.2007.4415111.

55. Jari Kätsyri, Beatrice de Gelder, and Tapio Takala. "Virtual Faces Evoke Only a Weak Uncanny Valley Effect: An Empirical Investigation with Controlled Virtual Face Images." PsyArXiv. July 17 (2018). Doi:10.1177/0301006619869134.

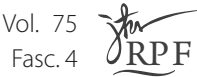


a wider range of variables other than appearance and behaviour and (2) for realistic, human-like characters, the Uncanny Valley is an impossible traverse, is not supported fully by empirical evidence and the concept is better replaced with the notion of an Uncanny Wall. ${ }^{56}$

Thus, an Uncanniness of temporal dissonance that is given in an after-moment of realization that the supposedly human is in fact a technical machine or artefact, in the sense of Tinwell is given in a constant collapse that we could call an epoché of the homely. Thus, the uncanny does not disappear once it is clear in the encounter that the machine is almost like us, but still not us at all. Therefore, in temporal habituation the uncanny is cemented as a "wall" that disables the epoché of the homely as difference again and again to surge from outside the familiar.

\subsubsection{Uncanny hands: From techno-hand shake to the plasticity of the body in the rubber hand illusion and OBE'S}

Mori introduced the Uncanny Valley in a mise-en-scéne of a typical close human-human encounter that he now turns into a human-robot encounter in the situation of a creepy nightly handshake with an prosthetic artificial hand ${ }^{57}$, in which touch is a confirmation/ negation of a visual human morphological shaped prosthetic hand and the clear function of the artificial hand is to substitute a missing human hand by a technical substitute. The Uncanny valley in the sense of the roboticist Mori, proposed in 1970, is first of all thought of as a graphical - mathematical curve or line that is interpreted as a valley. Mori reflects on the human affinity for movement that seems human like, even though programmed in which the velocity, acceleration, and deceleration should be mimicking human movement. On the other hand he is cautious about the contrary side effects of too much affinity that can't hold true over time when he refers to a prosthetic hand that in his diagram would be located near the bottom of the uncanny valley and then suddenly is observed in its movement that only intensifies the spectators sensation of eeriness.

56. Angela Tinwell, Mark Grimshaw, and Andrew Williams. “The Uncanny Wall.” International Journal of Arts and Technology 4, no. 3 (2011): 326. https://doi.org/10.1504/ijart.2011.041485.

57. Cf. Mori, 99-100.

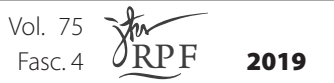




\section{Rubber Hand illusion and Out of Body Experiences}

Since the famous article of in Botvinick and Cohan (1998) the prolific "rubber hand illusion" 58 has become a model for multiple investigations into the flexibility and malleability and uncanniness of the proprioceptive body schema, and its forms of experimental-technical manipulations, regarding its $\operatorname{size}^{59}$ and its manipulation to effect aberrations in multisensory integrations such as autoscopic Out of Body experiences (OBE's) ${ }^{60}$ related to proprioceptive drift of the body schema towards the inclusion of artificial limbs of a rubber hand or transformation of self-localizations. The uncanniness in these strange phenomena are dealing with unstable or irregular senses of agency, attribution of mineness of a body and the localizations (Blanke \& Arzy 2005) of bodies in space. This phenomenological otherness of altered body experiences can be founded in the double notion of the body ${ }^{61}$ as a functional, physiological "Körper" that never fully corresponds to what a self might experience as "my" lived "Leib" including its proper body-image and body ownership and $1^{\text {st }}$ or second person perspective. In an extreme case on the level of neuropsychological ${ }^{62}$ and empirically informed philosophical research in the $\mathrm{LAB}^{63}$ with help of

58. Matthew Botvinick and Jonathan Cohen. "Rubber Hands 'Feel' Touch That Eyes See." Nature 391, no. 6669 (1998): 756-56. https://doi.org/10.1038/35784.

59. Cooke, E. A. G., and J. K. Oregan. "Size-Manipulation of the Body-Schema Using the Rubber Hand Illusion.” Journal of Vision 6, no. 6 (2010): 862-62. https://doi.org/10.1167/6.6.862.

60. Jason J. Braithwaite, Derrick G. Watson, and Hayley Dewe. "Predisposition to out-ofBody Experience (OBE) Is Associated with Aberrations in Multisensory Integration: Psychophysiological Support from a 'Rubber Hand Illusion' Study.” Journal of Experimental Psychology: Human Perception and Performance 43, no. 6 (2017): 1125 43. https://doi.org/10.1037/xhp0000406.

61. Mittelstrass, referring to Helmuth Plessner, distinguishes this double notion of the body very well that in German has two expressions "Leib" and "Körper": "On the basis for this distinction see Plessner (1970, 11-171). According to Plessner, man is his phenomenological body (Leib) and has it as a physical body (Körper); he is a Leib im Körper as opposed to an animal that is its (physical) body and has it as its phenomenological body (Plessner, 1982)." Mittelstrass, Jürgen. "The Limits of Science and the Limitations of Knowledge". ALLEA Biennial Yearbook 2002 (11-26). (Amsterdam: ALLEA 2002), 21.

62. Hongfang Wang, Eleanor Callaghan, Gerard Gooding-Williams, Craig Mcallister, and Klaus Kessler. "Rhythm Makes the World Go Round: An MEG-TMS Study on the Role of Right TPJ Theta Oscillations in Embodied Perspective Taking." Cortex 75 (2016): 68-81. https://doi.org/10.1016/j.cortex.2015.11.011.

63. Thomas K. Metzinger, "Why Are out-of-Body Experiences Interesting for Philosophers?" Cortex 45, no. 2 (2009): 256-58. https://doi.org/10.1016/j.cortex.2008.09.004.

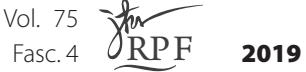


$\mathrm{VR}^{64}$ technology to render experimental induction ${ }^{65}$ and repeatability of these uncanny embodiment experiences available, and further, the possibility is tested if we can even create the illusion of swapping our entire body-schema by perceiving an artificial humanoid body as its own ${ }^{66}$ and project it outside our localized multisensory physiological body position ${ }^{67}$, a research that has parallels in the neuroscientific research of Out-of-Body experiences in which even an uncanny body shadow or an artificial feeling of presence ${ }^{68}$ can be technically induced and manipulated by electromagnetic stimulation of the brain ${ }^{69}$. Nevertheless, we don' ${ }^{70}$ have to assume a comparison of perceptual and internal body - models as a causal relation of a fixed self-model.

Recently the uncanny cybernetic idea of technological transhumanism in how far our body schema could embody more than two arms or hands has been put forward in a integration for example four ${ }^{71}$ prosthetic hands: But how exactly time ${ }^{72}$ does play a crucial factor in the uncanny

64. Thomas K. Metzinger, "Why Is Virtual Reality Interesting for Philosophers?” Frontiers in Robotics and AI 5 (2018). https://doi.org/10.3389/frobt.2018.00101.

65. H. H. Ehrsson, "The Experimental Induction of Out-of-Body Experiences." Science 317, no. 5841 (2007): 1048-48. https://doi.org/10.1126/science.1142175.

66. Valeria I. Petkova, and H. Henrik Ehrsson. "If I Were You: Perceptual Illusion of Body Swapping." PLoS ONE 3, no. 12 (March 2008). https://doi.org/10.1371/journal.pone.0003832.

67. B. Lenggenhager, T. Tadi, T. Metzinger, and O. Blanke. "Video Ergo Sum: Manipulating Bodily Self-Consciousness." Science 317, no. 5841 (2007): 1096-99. https://doi. org/10.1126/science.1143439.

68. The artistic project of Naomi Lea exploring the feeling of presence and the dis-and reembodied uncanny is very interesting to be explored further as her scientifically based art project makes us clear that the feelings of artificial presence are more widespread than often assumed: cf. Lea, Naomi. "The 'Ghost' in the Machine: the Feeling of Presence in a Computer-Mediated Environment.” Interactive Architecture Lab, October 30, 2018. http://www.interactivearchitecture.org/the-ghost-in-the-machine-the-feeling-ofpresence-in-a-computer-mediated-environment.html.

69. Shahar Arzy, Margitta Seeck, Stephanie Ortigue, Laurent Spinelli, and Olaf Blanke. "Induction of an Illusory Shadow Person." Nature 443, no. 7109 (2006): 287-87. https:// doi.org/10.1038/443287a.

70. Piotr Litwin, "Rubber Hand Illusion Does Not Arise from Comparisons with Internal Body Models: a New Multisensory Integration Account of the Sense of Ownership," 2018. https://doi.org/10.7287/peerj.preprints.27136.

71. Ellen Poliakoff, Sophie O’Kane, Olivia Carefoot, Peter Kyberd, and Emma Gowen. "Investigating the Uncanny Valley for Prosthetic Hands." Prosthetics and Orthotics International 42, no. 1 (2018): 21-27. https://doi.org/10.1177/0309364617744083.

72. Cf. The research of that propose that individual susceptibility to the rubber hand illusion would depend on individual temporal resolution in multisensory perception, as indexed by a temporal binding window: Costantini, Marcello, Jeffrey Robinson, Daniele Migliorati,

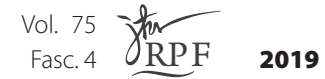

Provided for Personal License use. Not for reproduction, distribution, or commercial use. (C) 2019 Revista Portuguesa de Filosofia. All Rights Reserved. 
bodily integration of a non-animate rubber hand seems still insufficiently answered: For Tinwell and colleagues the uncanny valley cannot be passed through. That is the reason that they instead of an Uncanny Valley proposed an Uncanny Wall. In addition, this wall becomes higher because of another diachronic factor: the element of habituation. This factor of habituation in time leads to an increasing ability of viewers to judge technical tricks. This increasing refinement of differentiation is the reason why the wall is getting higher and higher over time for them. Mark Fisher on the other hand criticizes this idea of the overcoming of interior feeling if uncanniness that is a critic on Freud's interiority and opposes it to the Other that from outside forces us and is mostly non-human - that can be called the socio-technical uncanny that invades the subject with the experience of otherness:

The folding of the weird and the eerie into the unheimlich is symptomatic of a secular retreat from the outside. (...) The weird and the eerie make the opposite move: they allow us to see the inside from the perspective of the out side (...) the way that "we" "ourselves" are caught up in the rhythms, pulsions and patternings of non-human forces. There is no inside except as a folding of the outside; the mirror cracks, I am an other, and I always was. The shudder here is the shudder of the eerie, not of the unheimlich. ${ }^{73}$

\subsubsection{Uncanny feedback - towards a cybernetic technological uncanny}

We can access the uncanny as well with Michel Serres idea of the "parasite" in which the uncanny could be interpreted as unwelcomed noise $^{74}$ in communication, as a biological and even an artificial life form

Brunella Donno, Francesca Ferri, and Georg Northoff. “Temporal Limits on Rubber Hand Illusion Reflect Individuals' Temporal Resolution in Multisensory Perception." Cognition 157 (2016): 39-48. https://doi.org/10.1016/j.cognition.2016.08.010.

73. Mark Fisher, The Weird and the Eerie. (London: Repeater Books, 2016), 10-11.

74. "We are surrounded by noise. And this noise is inextinguishable. It is outside-it is the world itself-and it is inside, produced by our living body. We are in the noises of the world, we cannot close our door to their reception, and we evolve, rolling in this incalculable swell. We are hot, burning with life; and the hearths of this temporary ecstasy send out a truceless tumult from their innumerable functions. If these sources are stilled, death is there in the form of flat waves. Flat for recording, flat for closed ears. In the beginning is the noise; the noise never stops. It is our apperception of chaos, our apprehension of disorder, our only link to the scattered distribution of things. Hearing is our heroic opening to trouble and diffusion; other receptors assure us of order or, if they no longer give or receive, close immediately. None assure us that we are surrounded by fluctuation and that we are full of

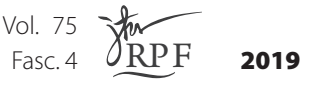


that lives off another and when realizing it it shocks us, or an unwelcomed guest that creeps in, a uncanny horror that calls us to order, a mediality that is time, something besides entropy ${ }^{75}$ and Darwinian evolution (irreversible time) mechanical (reversible time) and mathematical-logical (independent of time), a living social body becoming mathematical or programmable and thus independent of time may enter the zone of a "cybernetic uncanny". Thus, technological computational advances evoke even a "digital uncanny"76, that recur to computer-human ontological immanence as "uncanny networks"77. Moreover, the idea of the technology-driven transhumanist Elon Musk's civilizational project of merging humans with AI implants to not to be left behind a projected AI singularity or AI superintelligence in the near future, pushes Musk's brain-implant Neuralink ${ }^{78}$ company forward and proposes doubtful technological transhumanist trials on humans to connect our brains to the internet. This step of creating a human-internet network is justified as a techno-precautional escape strategy from becoming "housecats"79 of superintelligence AI in their uncontrolled takeover of machine singularity. Musk tries to address in this transhumanist manner the legitimate human substitution and annihilation ${ }^{80}$ anxiety.

Even AI faces and Full-body - Avatars such as Millie ${ }^{81}$ that are fed by

fluctuation. And it chases us from chaos; by the horror it inspires in us, it brings us back and calls us to order." Serres, Michel. The Parasite. Translated, with notes by Lawrence R. Scher, (Baltimore and London, The John Hopkins University Press, 1982), 126.

75. See Michel Serres, "The Origin of Language: Biology, Information Theory, \& Thermodynamics". In: Michel Serres. Hermes. Literature, Science, Philosophy. Edited by Josue V. Harari \& David F. Bell. (The John Hopkins University Press, Baltimore and London, 1982), 71-83.

76. Richard Coyne, "The Digital Uncanny" in: Turner, Phil, and Elisabeth Davenport, eds. Spaces, Spatiality and Technology. (Dordrecht: Springer, 2005), 5-18; cf. recently the book of Ravetto-Biagioli, Kriss. Digital Uncanny. (New York: Oxford University Press, 2019).

77. Geert Lovink, Uncanny Networks: Dialogues with the Virtual Intelligentsia. (Cambridge, MA: MIT Press, 2004).

78. M. P. Anjana, "Neuralink Implantation of Artificial Intelligence in Humanbeings." International Journal of Computer Sciences and Engineering 06, no. 03 (2018): 104-7; Elon Musk, and Neuralink. "An Integrated Brain-Machine Interface Platform With Thousands of Channels (Preprint)," September 2019. https://doi.org/10.2196/preprints.16194.

79. Every Elon Musk Interview. “ Every Elon Musk Interview." Elon Musk Explained the AI future - We will be House Cats - Neurolase Explanation interview, August 24, 2017. https://www.youtube.com/watch?v=hQ3wyxDWVcw.

80. Kathleen Richardson, An Anthropology of Robots and AI: Annihilation Anxiety and Machines. (New York, NY: Routledge, 2017).

81. Jeremy Kahn, “Meet 'Millie' The Avatar. She'd Like To Sell You A Pair Of

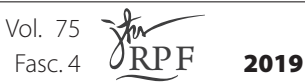


millions ${ }^{82}$ of human gesture samples can become part of uncanny artificial humans. Today, Avatars can be created with Machine Intelligence - but, as the case of Millie shows, are fed with human behavioural data - and thus can be seen in an uncanny feedback loop for instance of millions of human gestures that helped built a joint crowd-gestures as a commonsensical base for machine learning in convolutional neural networks ${ }^{83}$ to feed back on the gesture movements into direct feedbacks given from humans to Avatars and back to humans, as a human Avatar feedback loop. This Human-Avatar feedback loop can be designated uncanny crowd-gesture feedback. These feedbacks become uncanny with growing human-likeness, not only in appearance, but in behaviour that becomes indistinguishable from human gestures and as such become scary. These uncanny feedback loops are explored by artists such as Sue Hawksely's dance performance "Crosstalk" that Ravetto-Biagioli ${ }^{84}$ refers to in relation to interactive environment showing a cross-modal uncanniness and shift from automatic voice-recognition and textual projections to spatial relations of the dancer and her movement that trigger pre-recorded voices and shadows of the voice and movement of an actual live human performance.

This is as well the case in a "deep fake" 85 feedback loop of face-to-face capture $^{86}$ and targeting in real-time that is slightly dis-synchronized in

Sunglasses." NDTV.com, December 24, 2018. https://www.ndtv.com/world-news/ meet-millie-the-avatar-shed-like-to-sell-you-a-pair-of-sunglasses-1967335.

82. "The 20BN-Jester Dataset V1." Twenty Billion Neurons. Accessed November 1, 2019. https://20bn.com/datasets/jester/v1.

83. Pavlo Molchanov, Xiaodong Yang, Shalini Gupta, Kihwan Kim, Stephen Tyree, and Jan Kautz. "Online Detection and Classification of Dynamic Hand Gestures with Recurrent 3D Convolutional Neural Networks." 2016 IEEE Conference on Computer Vision and Pattern Recognition (CVPR), 2016. https://doi.org/10.1109/cvpr.2016.456.

84. Kriss Ravetto-Biagioli, Digital Uncanny. (New York: Oxford University Press, 2019), 97-142. https://doi.org/10.1093/oso/9780190853990.003.0004.

85. Facebook banned the use of Deep Fake from its social media platform, although other problems are not abridged by their ban:" To run afoul of the policy, a video has to meet two criteria: it must be manipulated "in ways that aren't apparent to an average person and would likely mislead someone into thinking that a subject of the video said words that they did not actually say," and it must be "the product of artificial intelligence or machine learning." What this leaves out, of course, is so-called "shallow fake" or "cheap fake" videos - the kind of selectively edited or out-of-context snippets that humans are already adept at creating and spreading." Gilad Edelman, "Facebook's Deepfake Ban Is a Solution to a Distant Problem." Wired. Conde Nast, January 7, 2020. https://www.wired. com/story/facebook-deepfake-ban-disinformation/.

86. Justus Thies, Michael Zollhofer, Marc Stamminger, Christian Theobalt, and Matthias Niebner. "Face2Face: Real-Time Face Capture and Reenactment of RGB Videos." 2016 IEEE Conference on Computer Vision and Pattern Recognition (CVPR), 2016. https://doi.

$$
\begin{aligned}
& \text { Vol. } 75 \text { Fasc. } 4 \text { RPF } \\
& 2019
\end{aligned}
$$


time and opposed of the target matching in AI-Puppeteering, in the "do as I do" motion retargeting putting everyone to dance in the same way, have to be critically considered in human-mimetic-artificially embodied AI in the research called "Everybody dance now" 87 where the dance movement is recorded of one person and transferred in a synchronized feedback loop reapplied to a target dancer.

\subsubsection{Uncanny voices: the acousmatic uncanny and artificial chatbots}

Independently if we take the uncanny valley as unscientific or not, or only reduced to the design field of Humanoids human-likeness in human-machine interaction, or based on a wider ground of human social psychology ${ }^{88}$, we agree that there has been a visual (Grimshaw ${ }^{89} 2009$ ) and as well perceptual motion bias in the uncanny valley. In relation to a metaphorological variation of the uncanny it has been noted besides the doubling motive (ghosts, doppelgänger, shadow person), that a strong visual metaphoric ${ }^{90}$ - and its ocularity/ specularity dynamics lies at the core of the uncanny. If we take the socio-technological uncanny in the encounter of human beings and artificial technical entities that are built-in human-likeness or in the extension of the initial language imitation to mimic any human-like features in an artificial technical object ${ }^{91}$, then it

org/10.1109/cvpr.2016.262.

87. Caroline Chan, Ginosar, Shiry, Zhou, Efros, and Alexei A. "Everybody Dance Now." arXiv.org, August 27, 2019. https://arxiv.org/abs/1808.07371.

88. Cf. Maya B. Mathur, and David B. Reichling. "Navigating a Social World with Robot Partners: A Quantitative Cartography of the Uncanny Valley." Cognition 146 (2016): 22-32. https://doi.org/10.1016/j.cognition.2015.09.008:3.

89. "What almost all studies dealing with the Uncanny Valley share, though, is a concentration on the image. Whether still or moving, such writings invariably deal with the appearance, and or motion, of the human-like character; there is a visual bias to the study of the uncanny." Grimshaw, Mark. "The audio Uncanny Valley: Sound, fear and the horror game." (2009). Games Computing and Creative Technologies: Conference Papers (PeerReviewed). Paper 9. http://digitalcommons.bolton.ac.uk/gcct_conferencepr/9 Available from: https://www.researchgate.net/publication/30502890_The_audio_Uncanny_Valley_ Sound_fear_and_the_horror_game [accessed Nov 02 2019].

90. Sadeq Rahimi, "The Ego, the Ocular, and the Uncanny: Why Are Metaphors of Vision Central in Accounts of the Uncanny?" The International Journal of Psychoanalysis 94, no. 3 (2013): 453-76. https://doi.org/10.1111/j.1745-8315.2012.00660.x. here: 453.

91. Cf. the extension of the Turing Test to a full embodied encounter and thus a maimal humantechnical object Turing Imitation games including for example passive and active touch in relation to human-like "sex-robots" in: Bultuc, Piotr (2017). "Church-Turing Lovers". In: Lin, Patrick, Keith Abney, and Ryan Jenkins, eds. Robot Ethics 2.0. From autonomous cars to artificial Intelligence. Oxford, New York: Oxford University Press: 214-228.

$$
\begin{aligned}
\text { Vol. } 75 \\
\text { Fasc. } 4
\end{aligned} \underset{\mathrm{RPF}}{2019}
$$


makes sense to extend the uncanniness discussion by reflecting on a metaphorological variation taking as well the following into account: sound, noise and acousmatic notions of temporality in the social-technological uncanny.

\section{Techno-social Reduced listening Modes: Uncanny voices}

Artificial Dialogue ${ }^{92}$ partners such as artificial digital AI assistants or chatbots are as well being studied in their uncanny valley effect ${ }^{93}$.

Our technological advancements are partly redefined by new media and the history of animated speaking or imitating animal sounding machines ${ }^{94}$ that use Artificial Intelligence (AI) algorithms in the sense of actually mimicking human-like artificial automata in a hyperrealistic style for instance uncanny robot voices ${ }^{95}$ of new digital assistants ${ }^{96}$ such as Siri, Alexa, Google Assistant, Cortana or even female robots such as Sophia ${ }^{97}$ or by digital speaking Avatars such as Millie and such computer generated images (CGI) copying almost all aspect of human morphology especially, a

92. Tinwell and colleagues worked on the notion of uncanniness and speech: Angela Tinwell, Mark Grimshaw, and Andrew Williams. "Uncanny Speech." Game Sound Technology and Player Interaction, n.d. https://doi.org/10.4018/9781616928285.ch011.

93. L. Ciechanowski, Przegalinska, A., Magnuski, M., \& Gloor, P. (2019). In the shades of the uncanny valley: An experimental study of human - chatbot interaction. Future Generations Computer Systems: FGCS, 92, 539-548.

94. Cf. Jessica Riskin, The Restless Clock: a History of the Centuries-Long Argument over What Makes Living Things Tick. Chicago: University of Chicago Press, 2018:111; cf. as well: Kang, Minsoo, “The Uncanny Automaton, 1789-1833”. In: Kang, Minsoo. Sublime Dreams of Living Machines: the Automaton in the European Imagination. (Cambridge, MA: Harvard University Press, 2011): 185-222.

95. Matt Simon, "The Uncanny Valley Nobody's Talking About: Eerie Robot Voices." Wired. Conde Nast, March 22, 2019. https://www.wired.com/story/uncanny-valley-robot-voices/.

96. Gaby Gayles, "Voice Assistants \& the Uncanny Valley: The More Lifelike, the Less 'Real."' Medium. Voice Tech Podcast, March 4, 2019. https://medium.com/voice-tech-podcast/ voice-assistants-the-uncanny-valley-the-more-lifelike-the-less-real-fb0bab2755d1. Refers to the AI engeneer Nikhil Mane at Autodesk that thinks that giving robotic names to Voice Assitants such as Siri ou Cortana might "lower expectations and reduce the uncanny valley phenomenon and associated cognitive dissonance. Until technology improves enough to make AI essentially indistinguishable from real humans, choosing a "robotic" name could keep voice assistants out of the uncanny valley."

97. Cf. "I am a real live electronic girl. I would like to go out into the world and live with people." Sophiabot in: Männistö, Tiina, Sivonen, Tanja, "Voices from the Uncanny Valley. How Robots and Artificial Intelligences Talk Back to Us." In: Ramón Reichert, Matthias Fuchs (eds.). Rethinking AI: Neural Networks, Biometrics and the New Artificial Intelligence. Digital Culture \& Society Vol4/1 (2018): 45-64.

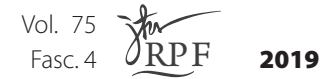


human (fictious) face, such as in face-swapping and its legal problematic ${ }^{98}$ and design for societal and ethical responsibility ${ }^{99}$, the morphing of movements and gestures onto others or even mimicking ${ }^{100}$, synthesizing ${ }^{101}$, cloning ${ }^{102}$, or faking the voice ${ }^{103}$ of an existent person.

For Levinas a re-reading of the surrealist Michel Leiris book "Biffures"(that he interprets not just as bifurcations but as "crossing out, or deletions"(Lévinas Outside the Subject, p.114) suggests that the universality of arts, specifically modern art derived from incompletion rather than completion, including painting is based on the "primacy of vision" (Lévinas 2008, 115)-and while reminding himself of the painter Lapique distinguishes emergence of spatial orders in painting in which (painted) things by the deletion delineate space. Lévinas hereby problematizes the sensible visual and spatial order, that for him lead to an immanent self-containment of the given (datum) phenomenal inside, but remains in the given order and does not go beyond the phenomenal existent world. He opposes thus to an order of sound, that in the end leads to the hearing as "repercussion, outburst scandal" (Lévinas, 116), that in its clearest form is given in the transcendence of the absolute metaphor of the "word", as hearing a word goes beyond the speaking voice of the other, that could be faked or economically enslaved in automatization.

98. Louise Matsakis and Jason Koebler. "Hacked Celebrity Nudes Show 'Freedom of Speech' Is Arbitrarily Defined By Internet Corporations." Vice, August 24, 2017. https:// www.vice.com/en_us/article/gyywax/hacked-celebrity-nudes-show-freedom-of-speechis-arbitrarily-defined-by-internet-corporations.

99. Cf.MarionBaylé, "Introducing'Designing ResponsiblywithAI'." Medium.UXCollective, March 23, 2019. https://uxdesign.cc/introducing-designing-responsibly-with-ai-b151045c4165.

100. Matthew Gault, "After 20 Minutes of Listening, New Adobe Tool Can Make You Say Anything." Vice, November 5, 2016. https://www.vice.com/en_us/article/jpgkxp/ after-20-minutes-of-listening-new-adobe-tool-can-make-you-say-anything.

101. Oliver Bendel, "The Synthetization of Human Voices." Ai \& Society 34, no. 1 (2017): 83-89. https://doi.org/10.1007/s00146-017-0748-x.

102. Samantha Cole, “'Deep Voice' Software Can Clone Anyone's Voice With Just 3.7 Seconds of Audio." Vice, March 7, 2018. https://www.vice.com/en_us/article/3k7mgn/ baidu-deep-voice-software-can-clone-anyones-voice-with-just-37-seconds-of-audio. Cf. AI Generated Voices Resemble AI.” Resemble AI. Accessed November 4, 2019. https://www.resemble.ai/.

103. "Lyrebird: Ultra-Realistic Voice Cloning and Text to Speech." Descript. Accessed November 4, 2019. https://www.descript.com/lyrebird-ai. Cf. Vincent, James. "Lyrebird Claims It Can Recreate Any Voice Using Just One Minute of Sample Audio." The Verge. The Verge, April 24, 2017. https://www.theverge.com/2017/4/24/15406882/ ai-voice-synthesis-copy-human-speech-lyrebird.

$$
\begin{aligned}
& \text { Vol. } 75 \\
& \text { Fasc. } 4 \text { RPF }
\end{aligned}
$$




\subsection{From uncanny aesthetic experience to "climate" and "atmosphere" in the beginning loss of reality}

The concept of the uncanny marks a strong presence not only in the fiction genres of horror film or horror games that by inducing immersive shock and fear experiences in the spectator or player achieve their fear effects or even study the listening to fear ${ }^{104}$, but as well in phenomenological and psychotherapeutic psychopathology not only in the version of Jentsch and Freud, but as well in Janet ${ }^{105}$ for instance by relating the topic of the Heimlich/unheimlich dynamics not necessarily to egologic neurotic variance of perception of my reality, but to the structural topos of a onset of fundamental dissociation in a climate or atmosphere that indicates a beginning "loss of reality"106, coming less from a estrangement of the familiar than from a "climate of strangeness" 107 and as seen from outside the individual subject. In relation to the topic of the uncanny around $1900^{108}$ in the middle of scientific debates on the empirical time subject in empirical psychology (Helmholz) and phenomenological approaches (Stumpf) such as inside a modern tempo of life, Erlmann speaks of

104. Guillaume Roux-Girard, "Listening to Fear." Game Sound Technology and Player Interaction, n.d., 192-212. https://doi.org/10.4018/978-1-61692-828-5.ch010.

105. Pierre Janet, Les Obsessions Et La psychasthénie. Tome I, (Paris: Alcan, 1919), 288-290.

106. "While both Janet and Freud confer upon the sense of strangeness a revelatory value within clinical manifestations of the vacillation of reality, Janet situates these phenomena in a continuity of the loss of the function of the real and of the predominance of automatism and oneirism, whereas Freud invites us to refer them to the subjective position with respect to the fantasy and the repression that is characteristic of neurosis." Troubé, Sarah Talila. "From the Uncanny to the Delusional Atmosphere | Cairn.info," November 2, 2015. https:// www.cairn.info/revue-recherches-en-psychanalyse-2015-1-page-32a.htm.

Cf. Ratcliffe, Matthew. "Delusional Atmosphere and the Sense of Unreality." Oxford Medicine Online, 2013. https://doi.org/10.1093/med/9780199609253.003.0015.

"Through its proximity to oneirism, to the fantasmatic sphere, or to archaic thought, the uncanny can appear to be a modality of those phenomena that are traditionally described as a "loss of reality."

107. "The impression of being targeted by elements of the environment, which the delusion could constitute as a determined enigma, is what distinguishes the climate of strangeness in the onset of psychosis from the momentary refusal to believe in a perception's reality, or a dissolution of more lasting reference points, that can come about in neurosis."

108. "Subjects around 1900 - Jentsch's "intellectually uncertain" listener no less than differential psychology's "asymptotic" individual and Simmel's "rare" individual - are like Debussy's Mélisande on her deathbed: They no longer see what they see, smell what they smell or, of course, hear what they hear. But least of all are they the selfreflexive Cartesian cogito or Kantian Ich they claim to be." Veit Erlmann, Reason and Resonance a History of Modern Aurality. (New York: Zone Books, 2014), 297-288.

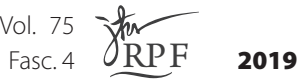


"uncanny recurrences" in relation to rhythmic spasms and early modern synesthetic disorientations, that reach new concretions around the 1940 in the Experiments of chronometrical brain-time, in which the separation of signal and time measurement can be suspended and since Stroud and Libet these empirical reaction time situations don't necessitate the direct control of an external experimenter anymore. ${ }^{109}$ With the 2008 AI algorithms ${ }^{110}$ crashing the stock market the beyond human reaction time machine ecology era is introduced in which we have to take action against the temporal algorithmic and computational acceleration of considering the impacts of its societal and political consequences such as de facto loss of autonomous human conscious action control.

The beginning atmosphere of delusion and reality loss Thomas Fuchs $^{111}$ (2019) following Schmitz ${ }^{112}$ handles within the concept of uncanny in the realm of the atmospheric that creeps in slowly and in growing fearfulness condenses towards an atmospheric sphere of fear growing into horror ${ }^{113}$. For Fuchs ${ }^{114}$ the atmosphere ${ }^{115}$ has a reality derived

109. Cf. Henning Schmidgen, Hirn und Zeit: Die Geschichte Eines Experiments 1800-1950. (Berlin: Matthes \& Seitz, 2014).

110. Johnson, N. et al. "Abrupt rise of new machine ecology beyond human response time", Nature Scientific Reports 3 (2013):2627. DOI: 10.1038/srep02627.

111. Thomas Fuchs. "The Uncanny as Atmosphere", Francesetti, Gianni, and Tonino Griffero, eds. Psychopathology and Atmospheres: Neither inside nor Outside. (Newcastle upon Tyne, UK: Cambridge Scholars Publishing, 2019), 101-118.

112. Hermann Schmitz, Der Gefühlsraum. (Bonn: Bouvier, 2005).

113. "The atmosphere of uncanny situations can also be described in the terminology of the German phenomenologist Hermann Schmitz as a "centripetal excitement". To designate this atmosphere, Schmitz introduces the word Bangnis (fearfulness), whereby he distinguishes it from fear as intentional feeling and from anxiety as a primarily bodily constriction. (...). Thereby the atmosphere does not appear abruptly, but rather creeps in, for ominous things at first only shine vaguely through the familiar. Bangnis becomes a horror, however, if the uncanny atmosphere condenses around certain objects and, at the same time, becomes physically threatening to the subject, thereby being connected to anxiety." Fuchs, 2019, $104 \mathrm{cf}$.

114. Thomas Fuchs, "The Experience of Time and its disorders". In: Stanghellini, Giovanni, Andrea Raballo, Matthew R. Broome, Anthony Vincent Fernandez, Paolo Fusar-Poli, and Rosfort René, eds. The Oxford Handbook of Phenomenological Psychopathology (Oxford: Oxford University Press, 2019), 1-13.

115. “This thesis of a Dasein's and Sosein's relativity of atmospheres does not place them in a psychic inner world, nor does it treat them as mere projections of psychological complexes. But neither is it a conception in which atmospheres and feelings are, as it were, existing independent of living beings, haunting them on certain occasions or in certain receptive states of mind. Rather, this conception understands atmospheres and moods as the encompassing whole of a particular, vitally significant relatedness of living beings and environment, such that this relationship is experienced in the way of affective concern, as emotion, affection, or even shock."

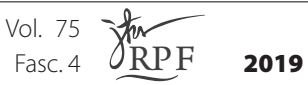


from "Dasein" (existential thereness) and "Sosein" - being as such and such in the concrete of the ecological dimension of reality outside and connected to the existence of living beings.

The problematic of hearing voices in the case of schizophrenic thought insertion can be described as uncanny voices.

For Thomas Fuchs, the intersubjective dimension of time is given in the synchronization/ a-synchronisation dynamics between world time and subjective time. It implies a tension between self and the others time and shows up in experience always already as a "too early" (acceleration; waiting/boredom, impatience, agitation, mania) or a "too late" (retardation; in illness, grief, guilt, depression, time pressure). It is expressed well in what in negation is "being at home with oneself" alias Heimat ${ }^{116}$, Levinas notion of time of the other.

\section{Outlook: Uncanny values?}

Let us remind ourselves on the metaphoric word transformation game that shifted the meaning for "weapons of mass destruction" as a narrative given to justify the US military intervention in Iraq, towards the later attributed narrative change of these narratives, have been a "weapons of mass distraction" of public opinion on non-existing mass destructive weapons. In another context of digitalization, big data and AI, the limits of mathematization of the world in the field of values, human social encounters and privacy and autonomy issues has been attributed the motto of a famous book "Weapons of math destruction" 117 in which human autonomy in a techno-social uncanniness is at seen risk. De facto autonomy as modulated by a datafied selfhood is based on infra-individual data and supra-individual patterns that leave out face-to-face encounters of human reflexive autonomous subjects. In the same line of thought the uncanny valley as a problem of designing less strange or paradoxical familiar-strange technological interfaces and technical objects, with increasing power attributed to these autonomous systems and agents that humans

116. When questioned about the impossible equivalent of the German word Heimat in French, he answered with alternatives to the one word concept: "On the contrary, patrie, chez soi, Bei-sich-sein, "to be with oneself"' Lévinas,Emmanuel, "Intention, Event and the Other" (140-157). In: Lèvinas, Emmanuel. Is It Righteous To Be?: Interviews with Emmanuel Levinas. Edited by Jill Robbins. (Palo Alto: Stanford University Press, 2001), 142.

117. Cathy O'Neil, Weapons of Math Destruction: How Big Data Increases Inequality and Threatens Democracy. (Great Britain: Penguin Books, 2017).

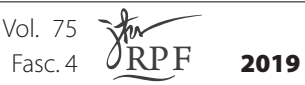


programmed, and by which we as humans are increasingly influenced in our social behaviour, the ethical question of values of social time as in Lévinas comes to the front. It transforms our idea of the "uncanny valley" in a metaphorological variation into the temporal and ethical other as uncanny values $^{118}$. But this metaphor shall be shown in another mise-enscène to follow up in the future. ${ }^{119}$

\section{References}

Another Life: Marlies Wirth on 'Uncanny Values. Artificial Intelligence \& You' at MAK - The Vienna Biennale for Change 2019.” Mousse Magazine, July 29, 2019. http://moussemagazine. it/marlies-wirth-chiara-moioli-uncanny-values-artificial-intelligence-and-you-mak-viennabiennale-for-change-2019/.

Anjana, M. P.. "Neuralink Implantation of Artificial Intelligence in Humanbeings.” International Journal of Computer Sciences and Engineering 06, no. 03 (2018): 104-7. https://doi. org/10.26438/ijcse/v6si3.104107.

Arzy, Shahar, Margitta Seeck, Stephanie Ortigue, Laurent Spinelli, and Olaf Blanke. "Induction of an Illusory Shadow Person." Nature 443, no. 7109 (2006): 287-87. https://doi. org/10.1038/443287a.

Baylé, Marion. "Introducing 'Designing Responsibly with AI'.” Medium. UX Collective, March 23, 2019. https:/uxdesign.cc/introducing-designing-responsibly-with-ai-b151045c4165.

Bartneck, Christoph, Takayuki Kanda, Hiroshi Ishiguro, and Norihiro Hagita. "Is The Uncanny Valley An Uncanny Cliff?" RO-MAN 2007 - The 16th IEEE International Symposium on Robot and Human Interactive Communication, 2007. https://oi.org/10.1109/roman.2007.4415111.

Bartneck, Christoph, Takayuki Kanda, Hiroshi Ishiguro, and Norihiro Hagita. "My Robotic Doppelgänger - a Critical Look at the Uncanny Valley." RO-MAN 2009 - The 18th IEEE International Symposium on Robot and Human Interactive Communication, 2009. https://doi. org/10.1109/roman.2009.5326351.

Beckert, Cristina. Subjectividade e Diacronia No Pensamento De E. Levinas. 2nd ed. Lisboa: Centro de Filosofia da Universidade de Lisboa, 2010.

Bendel, Oliver. "The Synthetization of Human Voices." Ai \& Society 34, no. 1 (2017): 83-89. https:// doi.org/10.1007/s00146-017-0748-x.

Botvinick, Matthew, and Jonathan Cohen. "Rubber Hands 'Feel' Touch That Eyes See." Nature 391, no. 6669 (1998): 756-56. https://doi.org/10.1038/35784.

118. As co-curator Paul Feigelfeld always says, "The data is polluted through us humans." The data are given to the machines by us humans, and we clearly are not in control - not about saving our resources and our planet, nor about social injustice or biases towards women, other genders, migration. Hence the question whether the machine can be a more democratic or a more just ruler than we humans is actually already corrupted: if it learns from us, it cannot. That's why this is the most important section out of the five [of the exhibition "Uncanny Values"; author's remark]."Another Life: Marlies Wirth on 'Uncanny Values. Artificial Intelligence \& You' at MAK - The Vienna Biennale for Change 2019” Mousse Magazine, July 29, 2019. http://moussemagazine.it/marlies-wirth-chiara-moioliuncanny-values-artificial-intelligence-and-you-mak-vienna-biennale-for-change-2019/.

119. Acknowledgement: This research is financed by portuguese national funds via FCT - Fundação para a Ciência e a Tecnologia, I.P., within the scope of the Transitional Standard - DL57/2016/CP CT[12343/2018- in the scientific field of History and Philosophy of Science and Technology, Position 2404, project: "Hacking Humans. Dramaturgies and Technologies of Becoming Other"

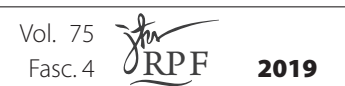


Blumenberg, Hans. Paradigms for Metaphorology[Paradigmen zu einer Metaphorologie, Frankfurt a.Main, Suhrkamp Verlag]. Translated from the German and with an afterword of Robert Savage. Ithaka New York, Cornell University Press, 2010.

Blumenberg, Hans. Quellen, Ströme, Eisberge. Ed. aus dem Nachlass by Bülow Ulrich von and Dorit Krusche. Berlin: Suhrkamp, 2012

Blumenberg, Hans. Paradigmen für eine Metaphorologie, Frankfurt am Main, Suhrkamp 2010.

Blumenberg, Hans. Theorie Der Unbegrifflichkeit. Hrg aus dem Nachlaß von Anselm Haverkamp. Frankfurt am Main: Suhrkamp, 2010

Blumenberg, Hans. Wirklichkeiten in denen wir leben. Stuttgart, Reclam 1981.

Braithwaite, Jason J., Derrick G. Watson, and Hayley Dewe. "Predisposition to out-of-Body Experience (OBE) Is Associated with Aberrations in Multisensory Integration: Psychophysiological Support from a 'Rubber Hand Illusion' Study." Journal of Experimental Psychology: Human Perception and Performance 43, no. 6 (2017): 1125-43. https://doi. org/10.1037/xhp0000406.

Bultuc, Piotr. "Church-Turing Lovers". In: Lin, Patrick, Keith Abney, and Ryan Jenkins, eds. Robot Ethics 2.0. From autonomous cars to artificial Intelligence. Oxford, New York: Oxford University Press, 2017: 214-228.

Chan, Caroline, Ginosar, Shiry, Zhou, Efros, and Alexei A. "Everybody Dance Now." arXiv.org, August 27, 2019. https://arxiv.org/abs/1808.07371.

Ciechanowski, L., Przegalinska, A., Magnuski, M., \& Gloor, P. (2019). In the shades of the uncanny valley: An experimental study of human - chatbot interaction. Future Generations Computer Systems: FGCS, 92: 539-548.

Cole, Samantha. “'Deep Voice' Software Can Clone Anyone's Voice With Just 3.7 Seconds of Audio." Vice, March 7, 2018. https://www.vice.com/en_us/article/3k7mgn/baidu-deep-voice-softwarecan-clone-anyones-voice-with-just-37-seconds-of-audio. Cf. AI Generated Voices Resemble AI." Resemble AI. Accessed November 4, 2019. https://www.resemble.ai/.

Collins, Jo, and John Jervis. Uncanny Modernity: Cultural Theories, Modern Anxieties. Basingstoke, Hampshire: Palgrave Macmillan, 2008.

Cooke, E. A. G., and J. K. Oregan. "Size-Manipulation of the Body-Schema Using the Rubber Hand Illusion.” Journal of Vision 6, no. 6 (2010): 862-62. https://doi.org/10.1167/6.6.862.

Costantini, Marcello, Jeffrey Robinson, Daniele Migliorati, Brunella Donno, Francesca Ferri, and Georg Northoff. “Temporal Limits on Rubber Hand Illusion Reflect Individuals' Temporal Resolution in Multisensory Perception." Cognition 157 (2016): 39-48. https://doi.org/10.1016/j. cognition.2016.08.010.

Coyne, Richard, "The Digital Uncanny" in: Turner, Phil, and Elisabeth Davenport, eds. Spaces, Spatiality and Technology. Dordrecht: Springer, 2005:5-18.

Derrida, Jacques. Spectres of Marx: the State of the Debt, the Work of Mourning, and the New International. New York: Routledge, 2011

Deutsches Wörterbuch von Jacob und Wilhelm Grimm. 16 Bde. in 32 Teilbänden. Leipzig 18541961. Quellenverzeichnis Leipzig 1971. halbzeug bis haldung (Bd. 10, Sp. 221 bis 223). Online-Version Wörterbuchnetz - Deutsches Wörterbuch von Jacob Grimm und Wilhelm Grimm. Accessed October 30, 2019. http://woerterbuchnetz.de/cgi-bin/WBNetz/wbgui_ py?sigle=DWB\&mode=Vernetzung\&lemid $=$ GH01348\#XGH01348.

Edelman, Gilad. "Facebook's Deepfake Ban Is a Solution to a Distant Problem." Wired. Conde Nast, January 7, 2020. https://www.wired.com/story/facebook-deepfake-ban-disinformation/.

Ehrsson, H. H. "The Experimental Induction of Out-of-Body Experiences." Science 317, no. 5841 (2007): 1048-48. https://doi.org/10.1126/science.1142175.

Erlmann, Veit. Reason and Resonance a History of Modern Aurality. New York: Zone Books, 2014.

Every Elon Musk Interview. “ Every Elon Musk Interview.” Elon Musk Explained the AI future - We will be House Cats - Neurolase Explanation interview, August 24, 2017. https://www.youtube. com/watch?v=hQ3wyxDWVcw.

Fisher, Mark. The Weird and the Eerie. London: Repeater Books, 2016.

Friedrich, Alexander, „Philosophisches Heimweh. Eine metaphorologische Studie zur Phänomenologie Edmund Husserls".In: Alexander Friedrich, Petra Gehring, and Andreas Kaminski, eds. „Metaphern Als Strenge Wissenschaft.”, Journal Phänomenologie 41/2014: $7-41$.

$$
\begin{aligned}
& \text { Vol. } 75 \\
& \text { Fasc. } 4 \text { RPF }
\end{aligned}
$$

Provided for Personal License use. Not for reproduction, distribution, or commercial use.

(c) 2019 Revista Portuguesa de Filosofia. All Rights Reserved. 
Fuchs, Thomas. "The Uncanny as Atmosphere". Francesetti, Gianni, and Tonino Griffero, eds. Psychopathology and Atmospheres: Neither inside nor Outside. Newcastle upon Tyne, UK: Cambridge Scholars Publishing, 2019:101-118.

Fuchs, Thomas. "The Experience of Time and its disorders". In: Stanghellini, Giovanni, Andrea Raballo, Matthew R. Broome, Anthony Vincent Fernandez, Paolo Fusar-Poli, and Rosfort René, eds. The Oxford Handbook of Phenomenological Psychopathology (pp.1-13). Oxford: Oxford University Press, 2019.

Gayles, Gaby. “Voice Assistants \& the Uncanny Valley: The More Lifelike, the Less 'Real.” Medium. Voice Tech Podcast, March 4, 2019. https://medium.com/voice-tech-podcast/voice-assistantsthe-uncanny-valley-the-more-lifelike-the-less-real-fb0bab2755d1.

Gault, Matthew. "After 20 Minutes of Listening, New Adobe Tool Can Make You Say Anything." Vice, November 5, 2016. https://www.vice.com/en_us/article/jpgkxp/after-20-minutes-oflistening-new-adobe-tool-can-make-you-say-anything.

Geller, Tom. "Overcoming the Uncanny Valley." IEEE Computer Graphics and Applications 28, no. 4 (2008): 11-17. https://doi.org/10.1109/mcg.2008.79.

González Cantón, César, "Absolutism: Blumenberg's Rhetoric as Ontological Concept" (pp103142). In: Alberto Fragio, Diego Giordano (eds.) Hans Blumenberg, Nuovi paradigmi d'analisi. Roma: Aracne, 2011.

Grimshaw, Mark. "The audio Uncanny Valley: Sound, fear and the horror game.." (2009). Games Computing and Creative Technologies: Conference Papers (Peer-Reviewed). Paper 9.http:// digitalcommons.bolton.ac.uk/gcct_conferencepr/9 Available from: https://www.researchgate. net/publication/30502890_The_audio_Uncanny_Valley_Sound_fear_and_the_horror_game [accessed Nov 02 2019].

Grunwald, Armin. "Are we heading towards an Enhancement Society?" In: Hildt, Elisabeth, Franke, Andreas G. (eds.).Cognitive Enhancement. An Interdisciplinary Perspective. Edited by Dordrecht: Springer Dordrecht, 2013: 201-216.

Haverkamp, Anselm. Hans Blumenberg, Paradigmen Zu Einer Metaphorologie Kommentar. Frankfurt, M.: Suhrkamp, 2013.

Heidegger, Martin. Der Satz Vom Grund. Gesamtausgabe. 1. Abteilung: veröffentlichte Schriften 19141970. Vol. 10. Frankfurt am Main: Klostermann, 1997.

Hunkin, Tim. "Fulfillment Centre In Use Youtube." YouTube.YouTube, February 12, 2019. https:// www.youtube.com/watch?time_continue $=1 \& v=N r 4 f d X t R J X Q \& f e a t u r e=e m b \_t i t l e$.

Husserl, Edmund, Zur Phänomenologie des inneren Zeitbewusstesens (1893-1917). Ed. R. Boehm. (= Husserliana X). The Hague: Martinus Nijhoff, 1969.

Jahnn, Hans Henny.Fluss Ohne Ufer: Roman in Drei Teilen. Edited by Ulrich Blitz. Hamburg: Hoffmann und Campe, 2014.

Janet, Pierre. Les Obsessions Et La psychasthénie. tome I, p. 288-290 Paris: Alcan, 1919.

Jentsch, Ernst. “On the Psychology of the Uncanny (1906)." Angelaki 2, no. 1 (1997): 7-16. https:// doi.org/10.1080/09697259708571910.

Johnson, Neil, Guannan Zhao, Eric Hunsader, Hong Qi, Nicholas Johnson, Jing Meng, and Brian Tivnan. "Abrupt Rise of New Machine Ecology beyond Human Response Time." Scientific Reports 3, no. 1 (November 2013). https://doi.org/10.1038/srep02627

Kaminski, Andreas, "Was heißt es, daß eine Metapher absolut ist? ", Journal Phänomenologie, In: Alexander Friedrich, Petra Gehring, and Andreas Kaminski, eds. Metaphern Als Strenge Wissenschaft. Journal Phänomenologie 41/2014 (2014), pp.47-62.

Kätsyri, Jari, Beatrice de Gelder, and Tapio Takala. 2018. "Virtual Faces Evoke Only a Weak Uncanny Valley Effect: An Empirical Investigation with Controlled Virtual Face Images." PsyArXiv. July 17. doi:10.1177/0301006619869134.

Kahn, Jeremy. "Meet 'Millie' The Avatar. She'd Like To Sell You A Pair Of Sunglasses.” NDTV.com, December 24, 2018. https://www.ndtv.com/world-news/meet-millie-the-avatar-shed-like-tosell-you-a-pair-of-sunglasses-1967335.

Kang, Minsoo,“The Uncanny Automaton, 1789-1833”. In: Kang, Minsoo. Sublime Dreams of Living Machines: the Automaton in the European Imagination. Cambridge, MA: Harvard University Press, 2011: 185-222.

Laclau, Ernesto. “The Time Is out of Joint."' Diacritics 25, no. 2 (1995): 85-96. https://doi. org/10.2307/465146.

$$
\begin{aligned}
& \text { Vol. } 75 \\
& \text { Fasc. } 4
\end{aligned}
$$

Provided for Personal License use. Not for reproduction, distribution, or commercial use.

(c) 2019 Revista Portuguesa de Filosofia. All Rights Reserved. 
Lea, Naomi. "The 'Ghost' in the Machine: the Feeling of Presence in a ComputerMediated Environment." Interactive Architecture Lab, October 30, 2018. http://www. interactivearchitecture.org/the-ghost-in-the-machine-the-feeling-of-presence-in-a-computermediated-environment.html.

Lenggenhager, B., T. Tadi, T. Metzinger, and O. Blanke. "Video Ergo Sum: Manipulating Bodily Self-Consciousness." Science 317, no. 5841 (2007): 1096-99. https://doi.org/10.1126/ science.1143439.

Lévinas, Emmanuel. Is It Righteous To Be? Interviews with Emmanuel Levinas. Edited by Jill Robbins. Palo Alto: Stanford University Press, 2001.

Lévinas, Emmanuel. “The Other, Utopia and Justice," in: Emmanuel Lévinas, Entre Nous. Thinking of the Other. Translated from the French by Michael B. Smith and Barbara Harshav, Columbia University Press: New York, 1989.

Lévinas, Emmanuel. Time and the Other: and Other Essays. Introduction. Translated by Richard A. Cohen. Pittsburgh, PA: Duquesne University Press, 1987.

Lévinas, Emmanuel. Otherwise than Being or beyond Essence. Translated by Alphonso Lingis. Originally published as Autrement qu'etre ou au-deLa de l'essence, Phaenomenologica 54 Boston: Martinus Nijhoff, 1991.

Libby, Willard F. Radiocarbon Dating. Chicago: The University of Chicago Press, 1955.

Litwin, Piotr. "Rubber Hand Illusion Does Not Arise from Comparisons with Internal Body Models: a New Multisensory Integration Account of the Sense of Ownership," 2018. https:// doi.org/10.7287/peerj.preprints.27136.

Lovink, Geert. Uncanny Networks: Dialogues with the Virtual Intelligentsia. Cambridge, MA: MIT Press, 2004.

Männistö, Tiina, Sivonen, Tanja, "Voices from the Uncanny Valley. How Robots and Artificial Intelligences Talk Back to Us.” In: Ramón Reichert, Matthias Fuchs (eds.). (Rethinking AI: Neural Networks, Biometrics and the New Artificial Intelligence. Digital Culture \& Society Vol4/1. 2018: 45-64.

Mathur, Maya B., and David B. Reichling. "Navigating a Social World with Robot Partners: A Quantitative Cartography of the Uncanny Valley." Cognition 146 (2016): 22-32. https:/doi. org/10.1016/j.cognition.2015.09.008:3.

Matsakis, Louise, and Jason Koebler. "Hacked Celebrity Nudes Show 'Freedom of Speech' Is Arbitrarily Defined By Internet Corporations.” Vice, August 24, 2017. https://www.vice.com/ en_us/article/gyywax/hacked-celebrity-nudes-show-freedom-of-speech-is-arbitrarily-definedby-internet-corporations.

Metzinger, Thomas K. "Why Is Virtual Reality Interesting for Philosophers?" Frontiers in Robotics and $A I 5$ (2018). https://doi.org/10.3389/frobt.2018.00101

Metzinger, Thomas K. "Why Are out-of-Body Experiences Interesting for Philosophers?" Cortex 45, no. 2 (2009): 256-58. https://doi.org/10.1016/j.cortex.2008.09.004.

Mittelstrass, Jürgen. "The Limits of Science and the Limitations of Knowledge". ALLEA Biennial Yearbook 2002 (pp.11-26). Amsterdam, ALLEA 2002.

Molchanov, Pavlo, Xiaodong Yang, Shalini Gupta, Kihwan Kim, Stephen Tyree, and Jan Kautz. "Online Detection and Classification of Dynamic Hand Gestures with Recurrent 3D Convolutional Neural Networks." 2016 IEEE Conference on Computer Vision and Pattern Recognition (CVPR), 2016. https://doi.org/10.1109/cvpr.2016.456.

Mori, Masahiro. "The Uncanny Valley." Translated by Karl Macdorman and Norri Kageki. IEEE Robotics \& Automation Magazine 19, no. 2 (June 6, 2012): 98-100. https://doi.org/10.1109/ mra.2012.2192811.Reprint from: M. Mori, “The uncanny valley," Energy, vol. 7, no. 4, pp. 33-35, 1970 (in Japanese).

Müller, Oliver, „Von der Theorie zur Praxis der Unbegrifflichkeit. Hans Blumenbergs Paraethik«, in: Anselm Haverkamp; Dirk Mende (Hg.): Metaphorologie. Zur Praxis von Theorie. Suhrkamp: Frankfurt a. M., 2009: 256-282.

Musk, Elon, and Neuralink. "An Integrated Brain-Machine Interface Platform With Thousands of Channels (Preprint)," September 2019. https://doi.org/10.2196/preprints.16194.

Newman, Kurt. "Panpsychism's Labyrinth. Steven Shaviro's New Book Teaches Us How to Navigate in a World Where Objects Are Peers." The New Inquiry, April 18, 2015. https://thenewinquiry. com/panpsychisms-labyrinth/.

$$
\begin{aligned}
& \text { Vol. } 75 \\
& \text { Fasc. } 4
\end{aligned}
$$


Nietzsche, Friedrich. Also sprach Zarathustra II, 180/30, Kritische Studienausgabe. V. Giorgio Colli \& Mazzino Montanari (eds.). München: dtv/de Gryther, 1988.

Ratcliffe, Matthew. "Delusional Atmosphere and the Sense of Unreality." Oxford Medicine Online, 2013. https://doi.org/10.1093/med/9780199609253.003.0015.

Petkova, Valeria I., and H. Henrik Ehrsson. "If I Were You: Perceptual Illusion of Body Swapping." PLoS ONE 3, no. 12 (March 2008). https://doi.org/10.1371/journal.pone.0003832.

Poliakoff, Ellen, Sophie O'Kane, Olivia Carefoot, Peter Kyberd, and Emma Gowen. "Investigating the Uncanny Valley for Prosthetic Hands." Prosthetics and Orthotics International 42, no. 1 (2018): 21-27. https://doi.org/10.1177/0309364617744083.

Rahimi, Sadeq. "The Ego, the Ocular, and the Uncanny: Why Are Metaphors of Vision Central in Accounts of the Uncanny?" The International Journal of Psychoanalysis 94, no. 3 (2013): 453-76. https://doi.org/10.1111/j.1745-8315.2012.00660.x.

Ravetto-Biagioli, Kriss. Digital Uncanny. New York: Oxford University Press, 2019: 97-142. https:// doi.org/10.1093/oso/9780190853990.003.0004.

Richardson, Kathleen. An Anthropology of Robots and AI: Annihilation Anxiety and Machines. New York, NY: Routledge, 2017.

Riskin, Jessica. The Restless Clock: a History of the Centuries-Long Argument over What Makes Living Things Tick. Chicago: University of Chicago Press, 2018.

Roux-Girard, Guillaume. "Listening to Fear." Game Sound Technology and Player Interaction, n.d., 192-212. https://doi.org/10.4018/978-1-61692-828-5.ch010.

Schmidgen, Henning. Hirn und Zeit: Die Geschichte Eines Experiments 1800-1950. Berlin: Matthes \& Seitz, 2014.

Schmitz, Hermann. Der Gefühlsraum. Bonn: Bouvier, 2005.

Serres, Michel. The Parasite. Translated, with notes by Lawrence R. Scher. Baltimore and London: The John Hopkins University Press, 1982.

Serres, Michel. "The Origin of Language: Biology, Information Theory, \& Thermodynamics". In: Michel Serres. Hermes. Literature, Science, Philosophy. Edited by Josue V. Harari \& David F. Bell. Baltimore and London: The John Hopkins University Press, 1982, p.71-83.

Simon, Matt. "The Uncanny Valley Nobody's Talking About: Eerie Robot Voices." Wired. Conde Nast, March 22, 2019. https://www.wired.com/story/uncanny-valley-robot-voices/.

Stein, Jan-Philipp, and Peter Ohler. "Venturing into the Uncanny Valley of Mind - The Influence of Mind Attribution on the Acceptance of Human-like Characters in a Virtual Reality Setting." Cognition 160 (2017): 43-50. https://doi.org/10.1016/j.cognition.2016.12.010

Strub, Christian, "Wer hat Angst vor grünen Gläsern? Eine These zur Historizität und Normativität der Metametaphorologie, In: In: Alexander Friedrich, Petra Gehring, and Andreas Kaminski, eds. "Metaphern Als Strenge Wissenschaft.", Journal Phänomenologie 41/2014: 57-62.

Strub, Cristian. "Gebäude, organisch verkettet. Zur Tropologie des Systems" (108-135), in: Haverkamp, Anselm. Metaphorologie: Zur Praxis Von Theorie. Frankfurt am Main: Suhrkamp, 2009.

Saygin, Ayse Pinar, Thierry Chaminade, Hiroshi Ishiguro, Jon Driver, and Chris Frith. "The Thing That Should Not Be: Predictive Coding and the Uncanny Valley in Perceiving Human and Humanoid Robot Actions." Social Cognitive and Affective Neuroscience 7, no. 4 (2011): 413-22. https://doi.org/10.1093/scan/nsr025.

Tegmark, Max. Life 3.O.: Being Human in the Age of Artificial Intelligence. New York (New York): Alfred A. Knopf, 2017.

Twenty Billion Neurons, "The 20BN-Jester Dataset V1." Accessed November 1, 2019. https://20bn. $\mathrm{com} /$ datasets/jester/v1.

Theunissen, Michael. Negative Theologie Der Zeit. Frankfurt am Main: Suhrkamp, 1991.

Tinwell, Angela, Mark Grimshaw, and Andrew Williams. "The Uncanny Wall." International Journal of Arts and Technology 4, no. 3 (2011): 326. https://doi.org/10.1504/ijart.2011.041485.

Tinwell, Angela, Mark Grimshaw, and Andrew Williams. "Uncanny Speech." Game Sound Technology and Player Interaction, n.d. https://doi.org/10.4018/9781616928285.ch011.

Troubé, Sarah Talila. "From the Uncanny to the Delusional Atmosphere | Cairn.info," November 2, 2015. https://www.cairn.info/revue-recherches-en-psychanalyse-2015-1-page-32a.htm.

Peirce, Charles S., Collected Papers. Edited by Arthur W. Burks and Arthur W. Burks. Harvard U.P. Oxford U.P., 1958.

Vincent, James. "Lyrebird Claims It Can Recreate Any Voice Using Just One Minute of Sample

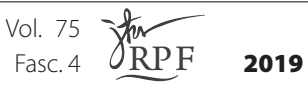

Provided for Personal License use. Not for reproduction, distribution, or commercial use.

(c) 2019 Revista Portuguesa de Filosofia. All Rights Reserved. 
Audio.” The Verge. The Verge, April 24, 2017. https://www.theverge.com/2017/4/24/15406882/ ai-voice-synthesis-copy-human-speech-lyrebird.

Wang, Hongfang, Eleanor Callaghan, Gerard Gooding-Williams, Craig Mcallister, and Klaus Kessler. "Rhythm Makes the World Go Round: An MEG-TMS Study on the Role of Right TPJ Theta Oscillations in Embodied Perspective Taking." Cortex 75 (2016): 68-81. https://doi. org/10.1016/j.cortex.2015.11.011.

Warren, Nicolas de. Husserl and the Promise of Time: Subjectivity in Transcendental Phenomenology. Cambridge: Cambridge University Press, 2009.

Waldenfels, Bernhard. Sozialität und Alterität: Modi Sozialer Erfahrung. Berlin: Suhrkamp, 2015.

Waldenfels, Bernhard, The Question of the Other. The Tang Chun-I Lecture for 2004. Hong Kong The Chinese University Press 2007.

Wiener, Norbert. God and Golem, Inc. A comment on certain points where cybernetics impinges on religion. Cambridge. Mass. MIT Press 1964. 